Article

\title{
The Effect of Different Starch Liberation and Saccharification Methods on the Microbial Contaminations of Distillery Mashes, Fermentation Efficiency, and Spirits Quality
}

\author{
Katarzyna Pielech-Przybylska ${ }^{1, *}$ (D), Maria Balcerek ${ }^{1}$ [D ${ }^{\text {, Agnieszka Nowak }}{ }^{2}$, Maciej Wojtczak ${ }^{3}$, \\ Agata Czyżowska ${ }^{2}$, Urszula Dziekońska-Kubczak ${ }^{1}$ and Piotr Patelski ${ }^{1}$ \\ 1 Department of Spirit and Yeast Technology, Institute of Fermentation Technology and Microbiology, \\ Faculty of Biotechnology and Food Sciences, Lodz University of Technology, Wolczanska 171/173, \\ 90-924 Lodz, Poland; maria.balcerek@p.lodz.pl (M.B.); urszula.dziekonska-kubczak@p.lodz.pl (U.D.-K.); \\ piotr.patelski@p.lodz.pl (P.P.) \\ 2 Department of Technical Microbiology, Institute of Fermentation Technology and Microbiology, \\ Faculty of Biotechnology and Food Sciences, Lodz University of Technology, Wolczanska 171/173, \\ 90-924 Lodz, Poland; agnieszka.nowak@p.lodz.pl (A.N.); agata.czyzowska@p.lodz.pl (A.C.) \\ 3 Institute of Food Technology and Analysis, Faculty of Biotechnology and Food Sciences, \\ Lodz University of Technology, Wolczanska 171/173, 90-924 Lodz, Poland; maciej.wojtczak@p.lodz.pl \\ * Correspondence: katarzyna.pielech-przybylska@p.lodz.pl
}

Received: 6 September 2017; Accepted: 29 September 2017; Published: 30 September 2017

\begin{abstract}
The aim of this study was to evaluate the influence of different starch liberation and saccharification methods on microbiological contamination of distillery mashes. Moreover, the effect of hop $\alpha$-acid preparation for protection against microbial infections was assessed. The quality of agricultural distillates was also evaluated. When applying the pressureless liberation of starch (PLS) and malt as a source of amylolytic enzymes, the lactic acid bacteria count in the mashes increased several times during fermentation. The mashes obtained using the pressure-thermal method and malt enzymes revealed a similar pattern. Samples prepared using cereal malt exhibited higher concentrations of lactic and acetic acids, as compared to mashes prepared using enzymes of microbial origin. The use of hop $\alpha$-acids led to the reduction of bacterial contamination in all tested mashes. As a result, fermentation of both mashes prepared with microbial origin enzyme preparations and with barley malt resulted in satisfactory efficiency and distillates with low concentrations of aldehydes.
\end{abstract}

Keywords: starch liberation; ethanol fermentation; malt; hop $\alpha$-acids; agricultural distillate

\section{Introduction}

Among the priority activities of the world economy, the major attention is paid to sustainable development, which takes into account the interactions between nature, economy, and society. The distilling industry is very conscious of environmental and social issues and has made significant contributions to energy and waste management improvement. One example that meets the requirements of sustainable development is promoting organic (bio) production, understood as a system of farm management and food production that combines the best environmental practices, protection of natural resources, application of high animal welfare standards, and the manufacturing methods complying with the requirements of consumers who prefer products made using natural substances and natural processes [1].

Nowadays, the production of ethanol from starchy raw materials in agricultural distilleries is based on the use of amylolytic enzymes of microbial origin, i.e., $\alpha$-amylase (EC 3.2.1.1) and 
amyloglucosidase (EC 3.2.1.3). However, the production of spirit beverages, such as Scotch, Irish, and American whisky, employs malt enzymes, including $\alpha$-amylase, $\beta$-amylase (EC 3.2.1.2), limit dextrinase (dextrin $\alpha$-1,6-glucanohydrolase, EC 3.2.1.41), proteases, glucanases, phosphatases, and lipases. Another example is the okovita, produced from grain distillate, which in accordance with the EU Regulation (European Commission, 2008) is defined as a spirit beverage produced exclusively by the distillation of a fermented mash of whole grain cereals and having the organoleptic characteristics of the raw materials used [2].

In the production of most grain spirits, malt enzymes have been replaced with commercial preparations including enzymes of microbial origin, which offer many advantages, such as high levels of activity in a wide temperature and $\mathrm{pH}$ range as well as long storage [3,4]. In turn, to maximize the activity of the native enzymes of plant origin (malt enzymes), it is necessary to strictly comply with appropriate temperature and $\mathrm{pH}$ conditions during starch hydrolysis, which are lower than those suitable for enzymes of microbial origin [5], that is, $70-75^{\circ} \mathrm{C}\left(\alpha\right.$-amylase) and $55-65^{\circ} \mathrm{C}$ ( $\beta$-amylase). To preserve the activity of both amylolytic malt enzymes in the mashing process, lower temperatures (not exceeding $50-56{ }^{\circ} \mathrm{C}$ ) are often used.

The advantage of the malt-based mashing process is the presence of numerous enzymes that hydrolyze cereal starch and non-starch components, thus providing nutrients to the yeast, as well as the occurrence of a wide range of aroma compounds [6]. One of the serious threats to the fermentation process is a low starch hydrolysis temperature, which may promote microbial contamination. In ethanol production, the most common microbial contaminants are lactic acid bacteria (LAB) [7], especially Lactobacillus, Lactococcus, Leuconostoc, and Pediococcus strains [8]. LAB ferment carbohydrates, producing lactic and acetic acids. They also compete for nutrients [9] and are resistant to ethanol concentrations above $10 \% v / v$, low $\mathrm{pH}$ (below 3.5), and high temperature, and thus hinder ethanol yield. The study of Muthaiyan et al. [10] shows that the gradual formation of acids during fermentation reduces the lifespan of yeast cells by up to $60 \%$. It has also been shown that the synergistic action of acetic and lactic acids decreases the yeast growth rate, the glucose consumption rate, and ethanol yield [10]. Broda and Leja [11] estimated the microbiological contamination of different unmalted cereal grains (corn, rye, and triticale) to be 4-8 log cfu of LAB per $g$ and approx. 4.5-7.5 log cfu of total viable bacteria per $\mathrm{g}$. On the other hand, $\mathrm{O}^{\prime}$ Sullivan et al. [12] investigated the malt microflora with a focus on $\mathrm{LAB}$, determining the degree of microbial contamination of barley before and during the malting process (wetting and germination), as well as at the end of the process (after drying).

In agricultural distilleries, both pressure-thermal and pressureless (PLS) methods of starch liberation are used in ethanol production. In the pressure-thermal method, raw materials are sterilized by high temperature $\left(150^{\circ} \mathrm{C}\right)$ and pressure $(0.5 \mathrm{MPa})$. In turn, the PLS method applies a temperature of $90{ }^{\circ} \mathrm{C}$ (approx. $60 \mathrm{~min}$ ), $120^{\circ} \mathrm{C}$ (approx. $20 \mathrm{~min}$ ), or $140{ }^{\circ} \mathrm{C}$ (approx. $3-4 \mathrm{~min}$ ). Sterilization is achieved above $120^{\circ} \mathrm{C}$, while a temperature of $90^{\circ} \mathrm{C}$ inactivates most viable vegetative forms of microorganisms, except for spores, which are heat-resistant. Nevertheless, secondary microbial contamination is possible in subsequent stages of processing due to the presence of microorganisms in the water, air, and yeast. Distillery equipment can also be a source of microbes [13].

One of the simplest and easiest methods to reduce growth of undesirable microflora, such as lactic bacteria, is lowering the $\mathrm{pH}$ of the fermented medium even to less than 4 value (e.g., with sulfuric acid). The optimal $\mathrm{pH}$ range for distillery yeast growth varied from 4 to 6. Narendranath and Power [14] found that lowering the $\mathrm{pH}$ of the mash to 4 reduces lactic acid production, without yeast growth inhibition. However, lactic acid bacteria, especially Lactobacilli, are usually more resistant to lower than optimal $\mathrm{pH}$ and able to grow in the medium with $\mathrm{pH}$ even close to 4.0.

The maintenance of microbiological purity could also be aided by the use of natural compounds of plant origin, limiting the development of undesirable microflora, particularly bacteria. Hop compounds exhibit antimicrobial activity, especially effective against bacterial contamination. Hop $\alpha$-acids inhibit the growth of Gram-positive bacteria, LAB included, by changing the permeability of bacteria cell membranes [15]. The undissociated forms of hop $\alpha$-acids diffuse through the membrane into the 
cell and decrease the intracellular $\mathrm{pH}$ of the bacteria, which in turn disrupts their nutrient uptake ability and stimulates the extracellular release of toxic metabolites [16]. Furthermore, Rückle and Senn [17] confirmed that hop $\alpha$-acids do not inhibit the activity of yeast during fermentation process. The combined effect of low $\mathrm{pH}$ of mashes and $\alpha$-hop acids seems to be a good idea to keep mashes safe from bacterial contamination during ethanol fermentation.

Taking into consideration the above assumptions, the aim of our study was to compare and assess the fermentation efficiency and microbial contamination of distillery mashes prepared with amylolytic enzymes of plant origin with those prepared with enzymes of microbial origin, via different methods of starch liberation and saccharification, as well as to evaluate the obtained agricultural distillates.

\section{Results and Discussion}

\subsection{Chemical Composition of Raw Materials}

Unmalted barley grain of the Karakan variety was used as raw material. As a source of amylolytic enzymes for starch hydrolysis, barley Munich malt type 2 was used. The starchy raw materials were analyzed for the content of moisture, reducing and total sugars, starch, and protein, with the results presented in Table 1.

Table 1. The chemical composition of raw materials.

\begin{tabular}{ccc}
\hline \multirow{2}{*}{ Components } & \multicolumn{2}{c}{ Content } \\
\cline { 2 - 3 } & Barley Variety Karakan & Barley Munich Malt Type 2 \\
\hline Moisture $(\mathrm{g} / \mathrm{kg})$ & $113.20 \pm 3.61 \mathrm{~b}$ & $43.40 \pm 1.42 \mathrm{a}$ \\
Reducing sugars $(\mathrm{g} / \mathrm{kg})$ & $71.70 \pm 2.40 \mathrm{a}$ & $184.30 \pm 8.43 \mathrm{~b}$ \\
Total sugars $(\mathrm{g} / \mathrm{kg})$ & $682.71 \pm 28.42 \mathrm{a}$ & $736.07 \pm 25.51 \mathrm{a}$ \\
Starch $(\mathrm{g} / \mathrm{kg})$ & $549.90 \pm 17.71 \mathrm{a}$ & $496.52 \pm 15.20 \mathrm{a}$ \\
Protein $(\mathrm{g} / \mathrm{kg}$ d.w.) & $97.04 \pm 5.13 \mathrm{a}$ & $95.60 \pm 3.33 \mathrm{a}$ \\
\hline
\end{tabular}

Different lower case letters in rows designate statistically significant differences $(p<0.05)$ between means (ANOVA, at a significance level of 0.05). d.w.-dry weight

Malted grain was found to have a lower moisture content $(p<0.05)$ than unmalted barley. The final stage of malt production involves drying. Wet malt is kilned to a final moisture content below $10 \%[18,19]$. The malt used in the study showed a low moisture content $(43.40 \pm 1.42 \mathrm{~g} / \mathrm{kg})$, typical for Munich malt [20]. The moisture of unmalted barley of the Karakan variety was consistent with data published in the literature [21]. The content of sugars (reducing, total, and starch) was also measured. The malted grain contained a significantly higher amount of reducing sugars in comparison with the unmalted grain $(p<0.05)$. The percentage of reducing sugars in total sugars in barley grain of the Karakan variety and in barley malt were $10 \%$ and $25 \%$, respectively.

\subsection{Chemical and Microbiological Characteristic of Mashes}

The distillery mashes were processed using two methods of starch liberation: pressure-thermal and pressureless. In both methods, the mashing process was carried out using both enzymatic preparations of microbial and plant origin. In order to examine the influence of starch liberation and saccharification methods on the microbial purity of sweet mashes and to assess the effect of hop $\alpha$-acids on microbial contamination, mashes were prepared in two variants: with and without hop $\alpha$-acid IsoStab ${ }^{\circledR}$ preparation.

Both sweet and fermented mashes were analyzed for $\mathrm{pH}$ and the content of extract, sugars (glucose, maltose, maltotriose, dextrins, and total sugars), and acids (lactic and acetic). In addition, ethanol concentration was determined in fermented mashes. The results are given in Tables 2 and 3. 
Table 2. Chemical composition of sweet mashes.

\begin{tabular}{|c|c|c|c|c|c|c|c|c|c|c|}
\hline \multirow{2}{*}{$\begin{array}{l}\text { Method of Starch } \\
\text { Liberation }\end{array}$} & \multirow{2}{*}{$\begin{array}{l}\text { Source of Amylolytic } \\
\text { Enzymes }\end{array}$} & \multirow{2}{*}{ Extract $(\mathrm{g} / \mathrm{kg})$} & \multirow{2}{*}{$\mathrm{pH}$} & \multicolumn{4}{|c|}{ Sugars $(g / L)$} & \multirow{2}{*}{$\begin{array}{l}\text { Total Sugars } \\
\text { (Glucose) (g/L) }\end{array}$} & \multicolumn{2}{|c|}{ Acids (g/L) } \\
\hline & & & & Glucose & Maltose & Maltotriose & Dextrins & & Lactic Acid & Acetic Acid \\
\hline \multirow{2}{*}{ PLS } & Barley Munich malt type 2 & $190.64 \pm 9.51 b$ & $4.8 \pm 0.1 \mathrm{a}$ & $4.06 \pm 0.14 a$ & $31.26 \pm 1.17 \mathrm{c}$ & $4.88 \pm 0.18 \mathrm{a}$ & $91.12 \pm 2.83 \mathrm{~b}$ & $164.70 \pm 6.29 \mathrm{~b}$ & $0.04 \pm 0.00 \mathrm{a}$ & $0.08 \pm 0.00 \mathrm{~b}$ \\
\hline & Termamyl S.C. SanExtra & $172.18 \pm 7.25 \mathrm{a}$ & $4.8 \pm 0.1 \mathrm{a}$ & $7.64 \pm 0.26 \mathrm{~b}$ & $16.25 \pm 0.61 \mathrm{~b}$ & $20.44 \pm 0.72 c$ & $102.84 \pm 3.19 c$ & $152.20 \pm 3.97 \mathrm{a}$ & ND & $0.04 \pm 0.00 \mathrm{a}$ \\
\hline \multirow{2}{*}{ Pressure-thermal } & Barley Munich malt type 2 & $191.19 \pm 11.05 b$ & $4.8 \pm 0.1 \mathrm{a}$ & $10.88 \pm 0.37 c$ & $41.23 \pm 1.54 \mathrm{~d}$ & $7.96 \pm 0.29 b$ & $66.13 \pm 2.05 a$ & $162.70 \pm 4.90 \mathrm{~b}$ & $0.05 \pm 0.00 \mathrm{a}$ & $0.12 \pm 0.00 \mathrm{~b}$ \\
\hline & Termamyl S.C. SanExtra & $175.89 \pm 10.08 \mathrm{a}$ & $4.8 \pm 0.1 \mathrm{a}$ & $35.14 \pm 1.20 \mathrm{~d}$ & $9.68 \pm 0.31 \mathrm{a}$ & $21.22 \pm 0.76 \mathrm{c}$ & $87.18 \pm 2.82 b$ & $150.40 \pm 3.69 a$ & ND & $0.16 \pm 0.00 \mathrm{c}$ \\
\hline
\end{tabular}

Different lower case letters in columns designate statistically significant differences $(p<0.05)$ between fermentation trials (Tukey's test, at a significance level of 0.05$)$. ND—not detected.

Table 3. Chemical composition of fermented mashes.

\begin{tabular}{|c|c|c|c|c|c|c|c|c|c|c|c|}
\hline \multirow{2}{*}{$\begin{array}{l}\text { Method of Starch } \\
\text { Liberation }\end{array}$} & \multirow{2}{*}{$\begin{array}{l}\text { Source of Amylolytic Enzymes/ } \\
\text { Addition of Hop } \alpha \text {-Acids (+ or - *) }\end{array}$} & \multirow{2}{*}{$\begin{array}{c}\text { Extract } \\
(\mathrm{g} / \mathrm{kg})\end{array}$} & \multirow{2}{*}{$\mathrm{pH}$} & \multicolumn{4}{|c|}{ Sugars $(\mathrm{g} / \mathrm{L})$} & \multirow{2}{*}{$\begin{array}{l}\text { Total Sugars } \\
\text { (Glucose) (g/L) }\end{array}$} & \multicolumn{2}{|c|}{ Acids $(\mathrm{g} / \mathrm{L})$} & \multirow{2}{*}{$\begin{array}{c}\text { Ethyl } \\
\text { Alcohol }(\mathrm{g} / \mathrm{L})\end{array}$} \\
\hline & & & & Glucose & Maltose & Maltotriose & Dextrins & & Lactic Acid & Acetic Acid & \\
\hline \multirow{4}{*}{ PLS } & Barley Munich malt type 2/- & $42.10 \pm 1.25 \mathrm{f}$ & $3.4 \pm 0.0 \mathrm{a}$ & $0.62 \pm 0.02 \mathrm{f}$ & $3.20 \pm 0.12 \mathrm{c}$ & $12.17 \pm 0.44 \mathrm{e}$ & $5.49 \pm 0.17 \mathrm{~b}$ & $28.80 \pm 0.49 \mathrm{ef}$ & $7.10 \pm 0.21 \mathrm{~d}$ & $0.62 \pm 0.01 \mathrm{e}$ & $53.30 \pm 1.82 \mathrm{a}$ \\
\hline & & & & $0.42 \pm 0.01 \mathrm{e}$ & $3.04 \pm 0.11 \mathrm{c}$ & & & & $0.26 \pm 0.01 \mathrm{ab}$ & $0.22 \pm 0.01 \mathrm{bc}$ & $66.40 \pm 2.43 \mathrm{~d}$ \\
\hline & Termamyl S.C. SanExtra/- & $34.64 \pm 1.12 \mathrm{e}$ & $3.5 \pm 0.1 \mathrm{a}$ & $0.04 \pm 0.00 \mathrm{a}$ & $0.38 \pm 0.01 \mathrm{~b}$ & $1.00 \pm 0.04 \mathrm{~b}$ & $9.48 \pm 0.29 \mathrm{~d}$ & $21.30 \pm 0.31 \mathrm{~cd}$ & $0.43 \pm 0.01 \mathrm{~b}$ & $0.24 \pm 0.01 \mathrm{c}$ & $59.18 \pm 2.19 b c$ \\
\hline & Termamyl S.C. SanExtra/+ & $31.05 \pm 0.97 \mathrm{~d}$ & $3.6 \pm 0.1 \mathrm{a}$ & $0.04 \pm 0.00 \mathrm{a}$ & $0.40 \pm 0.01 \mathrm{~b}$ & $0.96 \pm 0.03 \mathrm{~b}$ & $9.99 \pm 0.31 d$ & $12.10 \pm 0.46 \mathrm{de}$ & $0.19 \pm 0.01 \mathrm{ab}$ & $0.18 \pm 0.00 \mathrm{~b}$ & $63.28 \pm 2.36 c$ \\
\hline \multirow{4}{*}{ Pressure-thermal } & Barley Munich malt type 2/- & $22.34 \pm 0.86 c$ & $3.3 \pm 0.1 \mathrm{a}$ & $0.08 \pm 0.00 \mathrm{~b}$ & $0.18 \pm 0.01 \mathrm{a}$ & $6.34 \pm 0.23 \mathrm{~d}$ & $11.95 \pm 0.37 \mathrm{e}$ & $17.30 \pm 0.52 \mathrm{e}$ & $9.58 \pm 0.25 \mathrm{e}$ & $1.72 \pm 0.05 \mathrm{f}$ & $57.72 \pm 1.63 \mathrm{ab}$ \\
\hline & Barley Munich malt type 2/+ & $14.16 \pm 0.54 \mathrm{~b}$ & $3.9 \pm 0.1 \mathrm{c}$ & $0.09 \pm 0.00 \mathrm{~b}$ & $0.16 \pm 0.01 \mathrm{a}$ & $5.10 \pm 0.18 \mathrm{c}$ & $6.49 \pm 0.20 c$ & $7.60 \pm 0.25 a$ & $1.56 \pm 0.05 c$ & $0.34 \pm 0.01 \mathrm{~d}$ & $66.60 \pm 2.94 \mathrm{~d}$ \\
\hline & Termamyl S.C. SanExtra /- & $23.52 \pm 1.04 \mathrm{c}$ & $3.7 \pm 0.1 \mathrm{bc}$ & $0.24 \pm 0.01 \mathrm{~d}$ & $0.16 \pm 0.01 \mathrm{a}$ & $0.28 \pm 0.01 \mathrm{a}$ & $14.54 \pm 0.45 \mathrm{e}$ & $16.70 \pm 0.41 \mathrm{c}$ & $0.16 \pm 0.00 \mathrm{ab}$ & $0.19 \pm 0.01 \mathrm{bc}$ & $59.26 \pm 2.53 b c$ \\
\hline & Termamyl S.C. SanExtra/+ & $12.37 \pm 0.75 a$ & $3.8 \pm 0.1 \mathrm{bc}$ & $0.19 \pm 0.01 \mathrm{c}$ & $0.12 \pm 0.00 \mathrm{a}$ & $0.22 \pm 0.01 \mathrm{a}$ & $5.83 \pm 0.18 \mathrm{bc}$ & $6.90 \pm 0.22 \mathrm{a}$ & $0.04 \pm 0.00 \mathrm{a}$ & $0.12 \pm 0.00 \mathrm{a}$ & $66.71 \pm 2.27 \mathrm{~d}$ \\
\hline
\end{tabular}

Different lower case letters in columns designate statistically significant differences $(p<0.05)$ between fermentation trials (Tukey's test, at a significance level of 0.05$)$. ${ }^{*}+($ with addition of

hop $\alpha$-acids); - (without addition of hop $\alpha$-acids). 
In sweet mashes (fermentation time $0 \mathrm{~h}$ ), the concentration of glucose was higher $(p<0.05)$ in samples prepared by the pressure-thermal method as compared to the PLS method, using enzymes of both microbial and malt origin. Steaming led to profound changes in starch, involving gelatinization and then solubilization, making the subsequent hydrolysis of starch much more efficient [22,23]. Glucose concentration in sweet mashes after steaming was approx. 2.5-fold and 4.5-fold higher for enzymes of microbial origin and malt enzymes, respectively $(p<0.05)$, in comparison with mashes prepared by the PLS method (Table 2). Glucose concentration in sweet mashes was also affected by the enzymes used. Mashing grain with enzymes of microbial origin resulted in a more than 3-fold increase in glucose concentration in the sweet mash $(p<0.05)$ as compared to malt enzymes. This difference is attributable to the higher activity of enzymes of microbial origin. Moreover, malt $\beta$-amylase hydrolyzes starch, dextrin, and oligosaccharides to maltose, while amyloglucosidase of microbial origin hydrolyzes the above-mentioned products of $\alpha$-amylase activity into glucose molecules [4]. Therefore, the concentration of maltose in sweet mashes was 2-fold and 4.5-fold higher $(p<0.05)$ in samples using malt enzymes prepared by the PLS and pressure-thermal methods, respectively. High concentrations of dextrins $(p<0.05)$ were also observed in sweet mashes prepared with malt enzymes, which indicate the low initial saccharification. These mashes were also characterized with high concentrations of dextrins $(p<0.05)$ as a consequence of carrying out the process without the separate saccharification step.

Despite statistically significant differences in concentrations of sugars determined upon completion of fermentation, it can be observed that both mashes prepared with commercial enzyme preparations and with barley malt as a source of amylases have been fermented properly. The lowest amounts of unutilized glucose, maltose, maltotriose, and dextrins were determined in mashes supplemented with hop $\alpha$-acid preparation (Table 3 ).

Sweet mashes and mashes during fermentation were examined microbiologically. The results obtained for samples collected once every $24 \mathrm{~h}$ are shown in Table 4.

Table 4. Microbiological analysis of mashes.

\begin{tabular}{|c|c|c|c|c|c|}
\hline $\begin{array}{l}\text { Method } \\
\text { of Starch } \\
\text { Liberation }\end{array}$ & $\begin{array}{c}\text { Source of Amylolytic } \\
\text { Enzymes/Addition of Hop } \\
\alpha \text {-Acids }\left(+ \text { or }-{ }^{*}\right)\end{array}$ & $\begin{array}{c}\text { Time of } \\
\text { Fermentation } \\
\text { (h) }\end{array}$ & $\begin{array}{c}\text { Yeast }(Y) \\
\text { Count } \\
\log (\mathrm{cfu} / \mathrm{mL})\end{array}$ & $\begin{array}{c}\text { Lactic Acid } \\
\text { Bacteria (LAB) } \\
\text { Count } \\
\log (\mathrm{cfu} / \mathrm{mL})\end{array}$ & $\begin{array}{c}\text { Total Mesophilic } \\
\text { Bacteria (TMB) } \\
\text { Count } \\
\log (\mathrm{cfu} / \mathrm{mL})\end{array}$ \\
\hline \multirow{16}{*}{ PLS } & \multirow{4}{*}{ Barley Munich malt type 2/- } & 0 & $6.85 \pm 0.44 \mathrm{Ca}$ & $2.00 \pm 0.10 \mathrm{Ab}$ & $2.72 \pm 0.15 \mathrm{Ac}$ \\
\hline & & 24 & $8.41 \pm 0.40 \mathrm{Da}$ & $8.12 \pm 0.46 \mathrm{Be}$ & $7.47 \pm 0.32 \mathrm{Bd}$ \\
\hline & & 48 & $4.18 \pm 0.35 \mathrm{Ba}$ & $7.82 \pm 0.62 \mathrm{Bf}$ & $7.32 \pm 0.58 \mathrm{Bc}$ \\
\hline & & 72 & $2.54 \pm 0.25 \mathrm{Aa}$ & $7.08 \pm 0.63 \mathrm{Bc}$ & $7.11 \pm 0.63 \mathrm{Bc}$ \\
\hline & \multirow{4}{*}{ Barley Munich malt type 2/+ } & 0 & $6.85 \pm 0.44 \mathrm{Aa}$ & $2.00 \pm 0.10 \mathrm{Ab}$ & $2.72 \pm 0.15 \mathrm{Ac}$ \\
\hline & & 24 & $8.32 \pm 0.41 \mathrm{Ba}$ & $3.08 \pm 0.15 \mathrm{Bc}$ & $2.61 \pm 0.22 \mathrm{Aa}$ \\
\hline & & 48 & $8.08 \pm 0.34 \mathrm{Bb}$ & $3.61 \pm 0.30 \mathrm{Be}$ & $3.85 \pm 0.30 \mathrm{Bb}$ \\
\hline & & 72 & $8.40 \pm 0.25 \mathrm{Bd}$ & $3.34 \pm 0.33 \mathrm{Bc}$ & $3.54 \pm 0.31 \mathrm{Bb}$ \\
\hline & \multirow{4}{*}{ Termamyl S.C.; SanExtra /- } & 0 & $6.85 \pm 0.44 \mathrm{Aa}$ & $1.00 \pm 0.04 \mathrm{Aa}$ & $1.18 \pm 0.06 \mathrm{Ab}$ \\
\hline & & 24 & $8.04 \pm 0.90 \mathrm{Aa}$ & $3.85 \pm 0.22 \mathrm{Bd}$ & $4.11 \pm 0.22 \mathrm{Bb}$ \\
\hline & & 48 & $8.62 \pm 0.36 \mathrm{Bb}$ & $3.30 \pm 0.27 \mathrm{Be}$ & $4.26 \pm 0.34 \mathrm{Bbc}$ \\
\hline & & 72 & $8.98 \pm 0.82 \mathrm{Bd}$ & $3.04 \pm 0.30 \mathrm{Bc}$ & $3.58 \pm 0.31 \mathrm{Bb}$ \\
\hline & \multirow{4}{*}{ Termamyl S.C.; SanExtra/+ } & 0 & $6.85 \pm 0.44 \mathrm{Aa}$ & $1.00 \pm 0.04 \mathrm{Aa}$ & $1.18 \pm 0.06 \mathrm{Ab}$ \\
\hline & & 24 & $8.18 \pm 0.27 \mathrm{Ba}$ & $1.78 \pm 0.11 \mathrm{Bb}$ & $2.30 \pm 0.13 \mathrm{Ca}$ \\
\hline & & 48 & $7.95 \pm 0.25 \mathrm{Bb}$ & $<1.00 \mathrm{Aa}$ & $1.48 \pm 0.11 \mathrm{Ba}$ \\
\hline & & 72 & $8.28 \pm 0.34 \mathrm{Bd}$ & $<1.00 \mathrm{Aa}$ & $1.30 \pm 0.11 \mathrm{ABa}$ \\
\hline \multirow{8}{*}{ Pressure-thermal } & \multirow{4}{*}{ Barley Munich malt type 2/- } & 0 & $6.85 \pm 0.44 \mathrm{Aa}$ & $2.00 \pm 0.12 \mathrm{Ab}$ & $2.46 \pm 0.12 \mathrm{Ac}$ \\
\hline & & 24 & $8.53 \pm 0.70 \mathrm{Ba}$ & $4.34 \pm 0.26 \mathrm{Bd}$ & $5.11 \pm 0.26 \mathrm{Bc}$ \\
\hline & & 48 & $7.46 \pm 0.52 \mathrm{ABb}$ & $6.63 \pm 0.55 \mathrm{Cf}$ & $6.71 \pm 0.53 \mathrm{Cd}$ \\
\hline & & 72 & $6.15 \pm 0.47 \mathrm{Abc}$ & $7.18 \pm 0.71 C d$ & $7.87 \pm 0.69 \mathrm{Cc}$ \\
\hline & \multirow{4}{*}{ Barley Munich malt type 2/+ } & 0 & $6.85 \pm 0.44 \mathrm{Aa}$ & $2.00 \pm 0.12 \mathrm{Cb}$ & $2.46 \pm 0.12 \mathrm{Cc}$ \\
\hline & & 24 & $8.56 \pm 0.47 \mathrm{Ba}$ & $1.12 \pm 0.05 \mathrm{Ba}$ & $2.15 \pm 0.12 \mathrm{BCa}$ \\
\hline & & 48 & $8.62 \pm 0.40 \mathrm{Bb}$ & $1.48 \pm 0.12 \mathrm{Bbc}$ & $1.90 \pm 0.15 \mathrm{ABa}$ \\
\hline & & 72 & $8.48 \pm 0.42 \mathrm{Bd}$ & $<1.00 \mathrm{Aa}$ & $1.70 \pm 0.15 \mathrm{ABa}$ \\
\hline
\end{tabular}


Table 4. Cont.

\begin{tabular}{|c|c|c|c|c|c|}
\hline $\begin{array}{c}\text { Method } \\
\text { of Starch } \\
\text { Liberation }\end{array}$ & $\begin{array}{c}\text { Source of Amylolytic } \\
\text { Enzymes/Addition of Hop } \\
\alpha \text {-Acids }\left(+ \text { or }-{ }^{*}\right)\end{array}$ & $\begin{array}{c}\text { Time of } \\
\text { Fermentation } \\
\text { (h) }\end{array}$ & $\begin{array}{c}\text { Yeast }(Y) \\
\text { Count } \\
\log (\mathrm{cfu} / \mathrm{mL})\end{array}$ & $\begin{array}{c}\text { Lactic Acid } \\
\text { Bacteria (LAB) } \\
\text { Count } \\
\log (\mathrm{cfu} / \mathrm{mL})\end{array}$ & $\begin{array}{c}\text { Total Mesophilic } \\
\text { Bacteria (TMB) } \\
\text { Count } \\
\log (\mathrm{cfu} / \mathrm{mL})\end{array}$ \\
\hline \multirow{2}{*}{ Pressure-thermal } & Termamyl S.C.; SanExtra / - & $\begin{array}{c}0 \\
24 \\
48 \\
72\end{array}$ & $\begin{array}{c}6.85 \pm 0.40 \mathrm{Aa} \\
7.20 \pm 0.27 \mathrm{Aa} \\
8.18 \pm 0.27 \mathrm{Bb} \\
7.95 \pm 0.37 \mathrm{Bcd}\end{array}$ & $\begin{array}{c}<1.00 \mathrm{Aa} \\
1.00 \pm 0.05 \mathrm{Aa} \\
2.40 \pm 0.20 \mathrm{Bd} \\
3.18 \pm 0.31 \mathrm{Cc}\end{array}$ & $\begin{array}{c}<1.00 \mathrm{Aa} \\
4.40 \pm 0.24 \mathrm{Cb} \\
3.32 \pm 0.21 \mathrm{Bb} \\
3.30 \pm 0.29 \mathrm{Bb}\end{array}$ \\
\hline & Termamyl S.C.; SanExtra/+ & $\begin{array}{c}0 \\
24 \\
48 \\
72\end{array}$ & $\begin{array}{c}6.85 \pm 0.49 \mathrm{Aa} \\
8.43 \pm 0.20 \mathrm{Ba} \\
8.34 \pm 0.19 \mathrm{Bb} \\
8.04 \pm 0.22 \mathrm{Bcd}\end{array}$ & $\begin{array}{c}<1.00 \mathrm{Aa} \\
<1.00 \mathrm{Aa} \\
1.30 \pm 0.11 \mathrm{Bb} \\
1.18 \pm 0.12 \mathrm{Bb}\end{array}$ & $\begin{array}{c}<1.00 \mathrm{Aa} \\
2.11 \pm 0.13 \mathrm{Ca} \\
1.85 \pm 0.15 \mathrm{BCa} \\
1.60 \pm 0.13 \mathrm{Ba}\end{array}$ \\
\hline
\end{tabular}

Different capital letters in columns for each fermentation variant designate statistically significant differences $(p<0.05)$ between means (Tukey's test, at a significance level of 0.05). Different lower case letters in columns designate statistically significant differences $(p<0.05)$ between fermentation variants at the same time (Tukey's test, at a significance level of 0.05$){ }^{*}+$ (with addition of hop $\alpha$-acids); - (without addition of hop $\alpha$-acids).

Moreover, before and after fermentation, lactic and acetic acid content was determined in the mashes (Tables 2 and 3). The main sources of the microbial contaminations of distillery mashes are raw materials, water, and air. Additionally, the yeast and distillery equipment are an important factors in maintaining the proper purity of the process. Good practice is to use yeast disinfection (by sulfuric acid solution, $\mathrm{pH}$ 2-2.5) to eliminate undesirable bacterial cells, before mashes inoculation with yeast [24].

It was found that the use of malt in the mashing process greatly increased $(p<0.05)$ LAB and TMB counts. The LAB count was twice as high $(p<0.05)$ as that in the sample treated with enzyme preparations. O'Sullivan et al. [12] investigated that LAB count in kilned barley malt was $3.5 \times 10^{7} \mathrm{cfu} / \mathrm{g}$, while unmalted barley contained only $40-50 \mathrm{cfu} / \mathrm{g}$ of LAB.

The LAB and TMB counts in the mashes prepared using the PLS method with malt increased several times $(p<0.05)$ after the first day of fermentation, from $2.00 \pm 0.10$ to $8.12 \pm 0.46 \log \mathrm{cfu} / \mathrm{mL}$ and from $2.72 \pm 0.15$ to $7.47 \pm 0.32 \mathrm{log} \mathrm{cfu} / \mathrm{mL}(p<0.05)$, respectively, and afterwards remained at the same level until the end of fermentation $(p>0.05)$. The mashes obtained using the pressure-thermal method and malt enzymes exhibited a similar pattern, with the LAB and TMB counts doubling $(p<0.05)$ after $24 \mathrm{~h}$, and reaching $7.18 \pm 0.71$ and $7.87 \pm 0.69 \mathrm{log} \mathrm{cfu} / \mathrm{mL}$ at the end of the process, respectively. Broda and Leja [11] determined the LAB and TMB counts in distillery mashes. Before fermentation microbial contamination of different sweet mashes was 2-6 log cfu/mL (LAB) and 3-6 $\log \mathrm{cfu} / \mathrm{mL}$ (TMB), and after $72 \mathrm{~h}$ of fermentation increased to 5-8 $\log \mathrm{cfu} / \mathrm{mL}$ and $6.5-8 \log$ $\mathrm{cfu} / \mathrm{mL}$ for $\mathrm{LAB}$ and TMB, respectively. The growth of $\mathrm{LAB}$ and the fermentation of sugars result in the secretion of lactic and acetic acids into the medium, among others. HPLC analysis of fermented mashes showed a significantly higher $(p<0.05)$ concentration of lactic acid in samples prepared with malt $(7.10 \pm 0.21 \mathrm{~g} / \mathrm{L}$ for the PLS method and $9.58 \pm 0.25 \mathrm{~g} / \mathrm{L}$ for the pressure-thermal method $)$ in comparison with mashes prepared by starch hydrolysis with enzymes of microbial origin (Table 3). This was also true for acetic acid concentration, which was almost 3-fold and 9-fold higher in malt-based fermented mashes $(0.62 \pm 0.25 \mathrm{~g} / \mathrm{L}$ for the PLS method and $1.72 \pm 0.05 \mathrm{~g} / \mathrm{L}$ for the pressure-thermal method, respectively) $(p<0.05)$.

The synergistic activity of acetic and lactic acids has been shown to decrease the yeast growth rate, the glucose consumption rate, and ethanol yield [25,26]. Indeed, significantly $(p<0.05)$ lower ethanol content and fermentation efficiency were observed in trials exhibiting more severe bacterial contamination (Tables 2-5).

In comparison with trials involving enzymes of microbial origin, fermentation efficiency was lower for the PLS and pressure-thermal methods respectively $(p<0.05)$. Sugar intake was higher for all fermentation trials and reached $91.58 \pm 3.29 \%$ to $95.53 \pm 3.21 \%(p<0.05)$ due to sugar utilization by both yeast and bacteria (Table 5). Moreover, fermentation of mashes obtained by the PLS method with malt was accompanied by decreased yeast counts. Yeast count declined from $8.41 \pm 0.40 \log (\mathrm{cfu} / \mathrm{mL})$ at $24 \mathrm{~h}$ to $4.18 \pm 0.35 \log (\mathrm{cfu} / \mathrm{mL})$ at $48 \mathrm{~h}$ of fermentation with further reduction to $2.54 \pm 0.25 \log$ 
$(\mathrm{cfu} / \mathrm{mL})$ after $72 \mathrm{~h}(p<0.05)$. As regards mashes prepared by pressure-thermal treatment, a significant $(p<0.05)$ decrease in the yeast count was only observed between the second and third days of fermentation (from $7.46 \pm 0.52$ to $6.15 \pm 0.47 \log \mathrm{cfu} / \mathrm{mL}$ ).

Table 5. Ethanol fermentation factors.

\begin{tabular}{cccc}
\hline $\begin{array}{c}\text { Method of Starch } \\
\text { Liberation }\end{array}$ & $\begin{array}{c}\text { Source of Amylolytic Enzymes/Addition of Hop } \\
\boldsymbol{\alpha} \text {-Acids }\left(+\mathbf{o r}-{ }^{*} \text { ) }\right.\end{array}$ & $\begin{array}{c}\text { Intake of Total } \\
\text { Sugars (\%) }\end{array}$ & $\begin{array}{c}\text { Fermentation Efficiency } \\
\text { (\% of Theoretical) }\end{array}$ \\
\hline \multirow{3}{*}{ PLS } & Barley Munich malt type 2/- & $92.23 \pm 2.77 \mathrm{a}$ & $63.32 \pm 2.16 \mathrm{a}$ \\
& Barley Munich malt type 2/+ & $94.23 \pm 2.84 \mathrm{a}$ & $78.88 \pm 2.69 \mathrm{bc}$ \\
& Termamyl S.C.; SanExtra/- & $92.58 \pm 3.21 \mathrm{a}$ & $76.08 \pm 2.59 \mathrm{bc}$ \\
& Termamyl S.C.; SanExtra/+ & $92.05 \pm 3.78 \mathrm{a}$ & $81.35 \pm 2.77 \mathrm{~d}$ \\
\hline \multirow{5}{*}{ Pressure-thermal } & Barley Munich malt type 2/- & $91.58 \pm 3.29 \mathrm{a}$ & $69.41 \pm 2.37 \mathrm{a}$ \\
& Barley Munich malt type 2/+ & $95.33 \pm 4.21 \mathrm{a}$ & $80.09 \pm 3.53 \mathrm{~cd}$ \\
& Termamyl S.C.; SanExtra/- & $93.07 \pm 3.45 \mathrm{a}$ & $75.09 \pm 3.20 \mathrm{bc}$ \\
& Termamyl S.C.; SanExtra/+ & $95.53 \pm 3.21 \mathrm{a}$ & $84.53 \pm 2.88 \mathrm{~d}$ \\
\hline
\end{tabular}

Different lower case letters in columns designate statistically significant differences $(p<0.05)$ between fermentation variants (Tukey's test, at a significance level of 0.05$){ }^{*}+$ (with addition of hop $\alpha$-acids); - (without addition of hop $\alpha$-acids).

The most common antibacterial method used in distilleries is acid treatment with sulfuric acid. The sulfuric acid is used to reduce $\mathrm{pH}$ of sweet mashes as well as to yeast washing before mashes inoculation. During ethanol fermentation, the $\mathrm{pH}$ of mashes drops as a consequence of the removal of buffering compounds and release of organic acids. The major microbial contaminations of distillery mashes are bacteria, mainly lactic acid bacteria. The lactic acid bacteria grow in a wide $\mathrm{pH}$ range. Their optimum $\mathrm{pH}$ for growth depended on the strain and ranged from 5.5 to 6.9. However, lactic acid bacteria can also grow in the medium with a $\mathrm{pH}$ lower than optimum. This is due to a very well-functioning mechanism of $\mathrm{pH}$ gradient regulating [27,28].

The results of our study confirmed that lactic acid bacteria growth was observed in mashes with the initial $\mathrm{pH}$ of 4.8 , which dropped to 3.3-3.7 during ethanol fermentation (Table 3). Therefore, it seems necessary to use additional methods limiting the development of bacteria in the distillery mashes. The plant-based compounds are alternative antibacterial agents for antibiotics. This group is represented, for example, by hop acids, essential oils, lemon extract, phenolic compounds of green tea, etc. [10]. Hop compounds such as hop acids are recognized as safe for human [29].

The use of hop $\alpha$-acids was very effective in reducing bacterial contamination in mashes obtained by both the PLS and pressure-thermal methods with malt. In the case of PLS, the bacteria count in the mash fermented with hop $\alpha$-acids was reduced more than 2-fold (from $7.08 \pm 0.63$ to $3.34 \pm 0.33 \log$ $\mathrm{cfu} / \mathrm{mL}, p<0.05$ ) as compared to controls (without hop $\alpha$-acids), while in mashes obtained with the second method the presence of hop $\alpha$-acids resulted in a decrease in the LAB count to less than $1 \log$ $\mathrm{cfu} / \mathrm{mL}$ in comparison with the control sample $(7.18 \pm 0.71 \log \mathrm{cfu} / \mathrm{mL})(p<0.05)$. Reduced bacterial contamination was also observed in mashes prepared using the commercial enzyme preparations. After $72 \mathrm{~h}$, the bacteria count dropped to below $1 \log \mathrm{cfu} / \mathrm{mL}$, while bacterial contamination of the control (mash without hop $\alpha$-acids) reached $3.04 \pm 0.30 \log \mathrm{cfu} / \mathrm{mL}(p<0.05)$ (Table 4).

Rückle and Senn [17] examined the inhibitory potential of hop $\alpha$-acids to control Lactobacillus brevis and Lactobacillus fermentum strains during ethanol fermentation of wheat mashes inoculated with $10^{7} \mathrm{cfu} / \mathrm{mL}$ of the above-mentioned bacteria strains. The authors observed a reduction in bacteria counts to less than $10^{4} \mathrm{cfu} / \mathrm{mL}$, as well as a more than $90 \%$ decline in the concentration of lactic and acetic acids in mashes containing hop $\alpha$-acids (IsoStab ${ }^{\mathrm{TM}}$, Nürnberg, Germany) as compared to controls (without hop $\alpha$-acids). They noticed that a reduction in bacteria counts to less than $10^{6} \mathrm{cfu} / \mathrm{mL}$ efficiently inhibited bacteria metabolism with increasing ethanol yield.

Considering the microbial contamination of starchy raw materials, which are the main cause of distillery mashes infections, the pressure-thermal method, with the use of microbiological origin enzyme preparations, leads to the most favorable results in their elimination. Nevertheless, there is currently a trend to use energy-saving methods and produce bio-organic products. Therefore, changes 
in technology as well as in materials used in distilleries are being made. The implementation of environmental solutions in distillery technology greatly facilitates the processing of starch raw materials, but the shortcoming is the presence of bacteria that can effectively distort fermentation and reduce the quality of the obtained spirits. The combined use of PLS technology, the enzymes of plant origin, and $\alpha$-hop acids are in line with the current trend of using natural materials in spirit beverage production.

The Discriminant Function Analysis of Microbial Analysis Results

For evaluation of the results of microbial analysis (Table 4), the discriminatory power of the model was calculated, based on the discriminant function analysis. The assessment of discriminating power was estimated on the basis of Wilks' Lambda coefficient. In the discriminative function, the method of starch liberation, the source of amylolytic enzymes and the time of fermentation, as well as interactions between them were used as the variables. The validity of the model indicated groups that can be differentiated on the basis of the above three dependent variables (Table 6).

Table 6. Results of discriminant function analysis.

\begin{tabular}{|c|c|c|c|c|c|c|}
\hline Variable & $\begin{array}{c}\text { Microorganisms } \\
\log (\mathrm{cfu} / \mathrm{mL})\end{array}$ & $\begin{array}{l}\text { Significance of the } \\
\text { Model and } \\
\text { Discrimination }\end{array}$ & $\begin{array}{c}\text { Wilks' } \\
\text { Lambda * }\end{array}$ & $\begin{array}{l}\text { Wilks' } \\
\text { Part. * }\end{array}$ & $\mathrm{F}=1.92 *$ & $p^{*}$ \\
\hline \multirow{3}{*}{$\begin{array}{l}\text { Method of starch } \\
\text { liberation }\end{array}$} & $\mathrm{Y}$ & \multirow{3}{*}{$\begin{array}{c}\text { Wilks' Lambda: } 0.89085 \\
\mathrm{~F}(3.92)=3.7573 \\
p<0.0135\end{array}$} & 0.900 & 0.990 & 0.902 & 0.345 \\
\hline & LAB & & 0.979 & 0.910 & 9.134 & 0.003 \\
\hline & TMB & & 0.950 & 0.937 & 6.138 & 0.015 \\
\hline \multirow{3}{*}{$\begin{array}{l}\text { Source of amylolytic } \\
\text { enzyme }\end{array}$} & $\mathrm{Y}$ & \multirow{3}{*}{$\begin{array}{c}\text { Wilks' Lambda: } 0.01323 \\
\mathrm{~F}(45.232)=16.992 \\
p<0.0135\end{array}$} & 0.036 & 0.365 & 9.035 & $<0.01$ \\
\hline & LAB & & 0.026 & 0.505 & 5.100 & $<0.01$ \\
\hline & TMB & & 0.056 & 0.238 & 16.656 & $<0.01$ \\
\hline \multirow{3}{*}{ Time of fermentation } & $\mathrm{Y}$ & \multirow{3}{*}{$\begin{array}{c}\text { Wilks' Lambda: } 0.525 \\
\mathrm{~F}(9.219)=7.3776 \\
p<0.01\end{array}$} & 0.807 & 0.650 & 16.121 & $<0.01$ \\
\hline & LAB & & 0.532 & 0.988 & 0.374 & 0.772 \\
\hline & TMB & & 0.597 & 0.880 & 4.108 & 0.009 \\
\hline \multirow{3}{*}{$\begin{array}{l}\text { Method of starch } \\
\text { liberation } \times \text { Source of } \\
\text { amylolytic enzymes }\end{array}$} & $\mathrm{Y}$ & \multirow{3}{*}{$\begin{array}{c}\text { Wilks' Lambda: } 0.21241 \\
\mathrm{~F}(21.247)=8.4290 \\
p<0.01\end{array}$} & 0.292 & 0.726 & 4.629 & $<0.01$ \\
\hline & LAB & & 0.341 & 0.623 & 7.436 & $<0.01$ \\
\hline & TMB & & 0.274 & 0.775 & 3.573 & 0.002 \\
\hline \multirow{3}{*}{$\begin{array}{l}\text { Method of starch } \\
\text { liberation } \times \text { Time of } \\
\text { fermentation }\end{array}$} & $\mathrm{Y}$ & \multirow{3}{*}{$\begin{array}{c}\text { Wilks' Lambda: } 0.31851 \\
\mathrm{~F}(21.247)=5.7690 \\
p<0.01\end{array}$} & 0.504 & 0.631 & 7.170 & $<0.01$ \\
\hline & LAB & & 0.503 & 0.633 & 7.118 & $<0.01$ \\
\hline & TMB & & 0.511 & 0.623 & 7.425 & $<0.01$ \\
\hline \multirow{3}{*}{$\begin{array}{l}\text { Source of amylolytic } \\
\text { enzymes } \times \text { Time of } \\
\text { fermentation }\end{array}$} & $\mathrm{Y}$ & \multirow{3}{*}{$\begin{array}{c}\text { Wilks' Lambda: } 0.01323 \\
\mathrm{~F}(45.232)=16.992 \\
p<0.01\end{array}$} & 0.036 & 0.365 & 9.035 & $<0.01$ \\
\hline & LAB & & 0.026 & 0.505 & 5.100 & $<0.01$ \\
\hline & TMB & & 0.056 & 0.238 & 16.656 & $<0.01$ \\
\hline \multirow{3}{*}{$\begin{array}{l}\text { Method of starch } \\
\text { liberation } \times \text { Source of } \\
\text { amylolytic enzymes } \times \\
\text { Time of fermentation }\end{array}$} & $Y$ & \multirow{3}{*}{$\begin{array}{c}\text { Wilks' Lambda: } 0.00001 \\
\mathrm{~F}(93.186)=114.75 \\
p<0.01\end{array}$} & 0.000 & 0.074 & 24.856 & $<0.01$ \\
\hline & LAB & & 0.001 & 0.004 & 554.449 & $<0.01$ \\
\hline & TMB & & 0.001 & 0.004 & 505.327 & $<0.01$ \\
\hline
\end{tabular}

Y-yeast; LAB - lactic acid bacteria; TMB — total mesophilic bacteria. * The values of the discriminant function in bold are statistically significant.

The smaller values of the partial Wilks' Lambda coefficient indicated a stronger contribution of a given variable(s); thus, the variable or the interaction between the variables showed a stronger variation of yeast, lactic acid bacteria, and total bacteria counts. The results of cross-comparison of the source of amylolytic enzymes and the time of fermentation indicated the strongest differentiation of the total mesophilic bacteria, yeast, and lactic acid bacteria counts for which the partial Wilks' Lambda assumes the smallest value of $0.238,0.365$, and 0.505 , respectively. The weakest differentiation occurs only when we compare (without interaction) the method of starch liberation and the time of fermentation, where for yeast count (Wilks' part. $=0.990)$ and lactic acid bacteria count (Wilks' part. $=0.988)$ no significant differences were observed, respectively. Interactions between method of starch liberation, source of amylolytic enzymes and time of fermentation, resulted in the greatest differences in 
all counted microorganisms, i.e., TMB (Wilks' part. $=0.004)$, LAB (Wilks' part. $=0.004)$, and $\mathrm{Y}$ (Wilks' part. $=0.074$ ).

\subsection{Chemical Composition of the Obtained Distillates}

Following ethanol fermentation, distillery mashes contain, along with ethanol, a wide variety of volatile compounds synthesized by the yeast. The presence of other microorganisms (bacteria, wild yeast, or molds) can significantly affect the profile of volatile compounds. Cereals (both unmalted and malted) can also be a source of volatile compounds [6,30]. Analysis of the volatile profile of barley malt has revealed the presence of alcohols, aldehydes, ketones, esters, sulfur compounds, and others [6]. Some of these compounds may be considered as active sensory descriptors of the raw material in the resulting spirit (vodka), while others may be the intermediate products of the reactions occurring during yeast ethanol fermentation, imparting new sensory properties (sensory descriptors of fermentation). During the distillation process, most of them migrate to the produced spirits along with ethanol [31].

Upon completion of the fermentation and ethanol distillation, the obtained distillates were analyzed by gas chromatography, with the results given in Table 7. The evaluation of chemical composition involved carbonyl compounds, acetals, esters, alcohols, and acetic acid.

The obtained results were evaluated using variance analysis (ANOVA, $p<0.05$ ) followed by Tukey's multiple comparison test (Table 7). Significant differences in the concentration of volatile compounds were found between the various methods of starch liberation and hydrolysis (saccharification) $(p<0.05)$. Higher microbial contamination and metabolite concentration adversely affect yeast viability and fermentation activity. High levels of yeast viability and activity enable the reduction of aldehydes to corresponding alcohols, and in particular acetaldehyde to ethanol, while stress factors can significantly inhibit the activity of alcohol dehydrogenase [32]. Aldehyde presence may also be attributed to the oxidation reaction of alcohols [33]. In the obtained distillates, acetaldehyde levels were higher in the control samples of mashes (without hop $\alpha$-acids) prepared using both the PLS and the pressure-thermal methods $(p<0.05)$. The addition of anti-bacterial hop $\alpha$-acids to fermentation samples (PLS method) decreased acetaldehyde concentration in the distillates by $63 \%$ in the case of mash produced with malt and by $18 \%$ in the case of mash produced with commercial enzyme preparations $(p<0.05)$. A similar pattern was observed for the pressure-thermal method, in which acetaldehyde reduction amounted to over $40 \%(p<0.05)$. The concentrations of other carbonyl compounds, such as isobutyraldehyde, isovaleraldehyde, 2-methylbutyraldehyde, phenylacetaldehyde, furfural, and 2,3-butanedione were determined and found to decrease in the samples with microbial protection $(p<0.05)$. The presence of isovaleraldehyde and phenylacetaldehyde was only found in the distillates obtained from mashes prepared with malt. Indeed, these two aldehydes are compounds of malt origin. They are formed during malt production as a result of Maillard's reaction [34]. De Clippeleer et al. [35] reported them in malt and beer samples.

Some bacteria, among others of genera Lactobacillus and Leuconostoc, are able to form volatile compounds such esters, alcohols, and carbonyl compounds [36]. In the distillates obtained from mashes prepared with using malt as a source of enzymes, ethyl lactate (i.e., ethyl 2-hydroxypropanoate) was presented in higher concentration, but only in trials without microbial protection $(p<0.05)$. Respectively, the presence of a large number of lactic acid bacteria was found in these samples of mashes (Table 4). High level of ethyl lactate, with increasing levels of microbial contamination was also observed in other studies [37]. 
Table 7. Chemical composition of the obtained distillates.

\begin{tabular}{|c|c|c|c|c|c|c|c|c|}
\hline \multirow[b]{3}{*}{ Volatile Compounds } & \multicolumn{4}{|c|}{ Method of Starch Liberation \& Source of Enzymes } & \multirow{2}{*}{\multicolumn{4}{|c|}{ Pressure-thermal }} \\
\hline & \multicolumn{4}{|c|}{ PLS } & & & & \\
\hline & $\begin{array}{l}\text { Enzymes: Munich } \\
\text { Malt Type } 2 \\
\text { without Addition } \\
\text { of Hop } \alpha \text {-Acids }\end{array}$ & $\begin{array}{l}\text { Enzymes: Munich } \\
\text { Malt Type } 2 \text { with } \\
\text { Addition of Hop } \\
\alpha \text {-Acids }\end{array}$ & $\begin{array}{l}\text { Enzymes: Termamyl } \\
\text { S.C.; SanExtra } \\
\text { without Addition } \\
\text { of Hop } \alpha \text {-Acids }\end{array}$ & $\begin{array}{l}\text { Enzymes: Termamyl } \\
\text { S.C.; SanExtra } \\
\text { with Addition } \\
\text { of Hop } \alpha \text {-Acids }\end{array}$ & $\begin{array}{l}\text { Enzymes: Munich } \\
\text { Malt Type } 2 \\
\text { without Addition } \\
\text { of Hop } \alpha \text {-Acids }\end{array}$ & $\begin{array}{l}\text { Enzymes: Munich } \\
\text { Malt Type } 2 \\
\text { with Addition } \\
\text { of Hop } \alpha \text {-Acids }\end{array}$ & $\begin{array}{l}\text { Enzymes: Termamyl } \\
\text { S.C.; SanExtra } \\
\text { without Addition } \\
\text { of Hop } \alpha \text {-Acids }\end{array}$ & $\begin{array}{c}\text { Enzymes: Termamyl } \\
\text { S.C.; SanExtra } \\
\text { with Addition } \\
\text { of Hop } \alpha \text {-Acids }\end{array}$ \\
\hline CARBONYL COMPOUNDS & \multicolumn{8}{|c|}{ (mg/L of absolute alcohol) } \\
\hline Acetaldehyde & $34.247 \pm 0.982 \mathrm{e}$ & $12.842 \pm 0.357 \mathrm{~b}$ & $41.952 \pm 1.187 \mathrm{f}$ & $34.247 \pm 0.997 \mathrm{e}$ & $17.123 \pm 0.511 \mathrm{c}$ & $10.098 \pm 0.239 a$ & $29.966 \pm 0.758 \mathrm{~d}$ & $15.103 \pm 0.444 \mathrm{bc}$ \\
\hline Furfural & $225.807 \pm 6.475 \mathrm{e}$ & $79.700 \pm 2.213 \mathrm{~b}$ & $43.532 \pm 1.231 \mathrm{a}$ & $49.774 \pm 1.448 \mathrm{a}$ & $271.249 \pm 8.090 \mathrm{f}$ & $120.366 \pm 2.851 \mathrm{~d}$ & $95.501 \pm 2.416 \mathrm{c}$ & $50.400 \pm 1.482 \mathrm{a}$ \\
\hline Isobutyraldehyde & $4.214 \pm 0.121 \mathrm{~d}$ & $2.536 \pm 0.070 \mathrm{~b}$ & $3.567 \pm 0.101 \mathrm{c}$ & $1.866 \pm 0.054 a$ & $6.233 \pm 0.186 \mathrm{f}$ & $2.107 \pm 0.050 \mathrm{a}$ & $5.611 \pm 0.142 \mathrm{e}$ & $1.754 \pm 0.052 \mathrm{a}$ \\
\hline Isovaleraldehyde & $14.632 \pm 0.420 \mathrm{c}$ & $10.302 \pm 0.286 \mathrm{~b}$ & ND & $\mathrm{ND}$ & $61.866 \pm 1.845 \mathrm{e}$ & $40.214 \pm 0.952 \mathrm{~d}$ & $\mathrm{ND}$ & ND \\
\hline 2-Methylbutyraldehyde & $5.348 \pm 0.153 c$ & $3.268 \pm 0.091 \mathrm{~b}$ & $8.211 \pm 0.232 \mathrm{~d}$ & $5.765 \pm 0.168 c$ & $21.898 \pm 0.653 \mathrm{f}$ & $9.412 \pm 0.223 \mathrm{e}$ & $3.416 \pm 0.086 \mathrm{~b}$ & $1.997 \pm 0.059 \mathrm{a}$ \\
\hline Phenylacetaldehyde & $6.766 \pm 0.194$ & $3.819 \pm 0.106 \mathrm{~b}$ & ND & ND & $11.322 \pm 0.338 \mathrm{e}$ & $7.895 \pm 0.187 \mathrm{~d}$ & $\mathrm{ND}$ & $\mathrm{ND}$ \\
\hline 2,3-Butanedione & $8.416 \pm 0.241 \mathrm{c}$ & $6.188 \pm 0.172 \mathrm{ab}$ & $53.537 \pm 1.514 \mathrm{e}$ & $40.783 \pm 1.187 \mathrm{~d}$ & $6.722 \pm 0.200 \mathrm{ab}$ & $3.455 \pm 0.082 \mathrm{a}$ & $64.029 \pm 1.620 \mathrm{f}$ & $30.841 \pm 0.907 \mathrm{c}$ \\
\hline ACETALS & \multicolumn{8}{|c|}{ (mg/L of absolute alcohol) } \\
\hline Acetaldehyde diethyl acetal & $70.334 \pm 2.017 \mathrm{a}$ & $63.823 \pm 1.772 a$ & $214.836 \pm 6.077 \mathrm{e}$ & $176.780 \pm 5.145 \mathrm{~d}$ & $112.472 \pm 3.355 b$ & $101.720 \pm 2.409 \mathrm{~b}$ & $154.424 \pm 3.907 \mathrm{c}$ & $109.086 \pm 3.207 \mathrm{~b}$ \\
\hline Isobutyraldehyde diethyl acetal & $1.872 \pm 0.054 \mathrm{e}$ & $0.917 \pm 0.025 \mathrm{~b}$ & $3.487 \pm 0.099 \mathrm{~d}$ & $3.494 \pm 0.102 \mathrm{~d}$ & $6.153 \pm 0.184 \mathrm{f}$ & $1.296 \pm 0.031 \mathrm{c}$ & ND & ND \\
\hline Isovaleraldehyde diethyl acetal & $4.276 \pm 0.123 \mathrm{~b}$ & $4.233 \pm 0.118 \mathrm{~b}$ & ND & $\mathrm{ND}$ & $9.915 \pm 0.296 c$ & $\mathrm{ND}$ & ND & $\mathrm{ND}$ \\
\hline ESTERS & \multicolumn{8}{|c|}{ (mg/L of absolute alcohol) } \\
\hline Ethyl acetate & $502.371 \pm 14.405 c$ & $498.964 \pm 13.854 c$ & $282.430 \pm 7.989 a$ & $306.258 \pm 8.913 a$ & $953.045 \pm 28.425 \mathrm{~d}$ & $962.153 \pm 22.787 \mathrm{~d}$ & $417.976 \pm 10.576 \mathrm{~b}$ & $410.906 \pm 12.080 \mathrm{~b}$ \\
\hline Isoamyl acetate & $3.448 \pm 0.099 \mathrm{e}$ & $3.792 \pm 0.105 \mathrm{~d}$ & $3.618 \pm 0.102 \mathrm{c}$ & $3.822 \pm 0.111 \mathrm{c}$ & $2.983 \pm 0.089 \mathrm{c}$ & $2.912 \pm 0.069 \mathrm{~b}$ & $2.811 \pm 0.071 \mathrm{~b}$ & $2.735 \pm 0.080 \mathrm{a}$ \\
\hline Ethyl hexanoate & $2.916 \pm 0.084 \mathrm{~b}$ & $3.038 \pm 0.084 \mathrm{~b}$ & $2.234 \pm 0.063 a$ & $1.977 \pm 0.058 \mathrm{a}$ & $2.035 \pm 0.061 \mathrm{a}$ & $1.989 \pm 0.047 \mathrm{a}$ & $6.205 \pm 0.157 \mathrm{~d}$ & $5.289 \pm 0.155 c$ \\
\hline Ethyl octanoate & $11.512 \pm 0.330 \mathrm{~d}$ & $10.616 \pm 0.295 \mathrm{~b}$ & $8.393 \pm 0.237 \mathrm{c}$ & $7.627 \pm 0.222 \mathrm{~b}$ & $7.907 \pm 0.236 \mathrm{a}$ & $6.746 \pm 0.160 \mathrm{a}$ & $6.349 \pm 0.161 \mathrm{~b}$ & $5.103 \pm 0.150 \mathrm{~b}$ \\
\hline Ethyl decanoate & $1.708 \pm 0.049 \mathrm{~b}$ & $1.725 \pm 0.048 \mathrm{~b}$ & $1.399 \pm 0.040 \mathrm{a}$ & $1.356 \pm 0.039 a$ & $2.022 \pm 0.060 \mathrm{c}$ & $1.921 \pm 0.045 \mathrm{c}$ & $1.334 \pm 0.034 a$ & $1.256 \pm 0.037 \mathrm{a}$ \\
\hline Ethyl hexadecanoate & $8.642 \pm 0.248 \mathrm{~d}$ & $3.669 \pm 0.102 b$ & $6.202 \pm 0.175 c$ & $3.909 \pm 0.114 \mathrm{~b}$ & $1.179 \pm 0.035 \mathrm{a}$ & $1.202 \pm 0.028 \mathrm{a}$ & $3.535 \pm 0.089 \mathrm{~b}$ & $3.518 \pm 0.103 \mathrm{~b}$ \\
\hline 2-Phenylethyl isobutyrate & $2.178 \pm 0.062 \mathrm{~d}$ & $2.055 \pm 0.057 \mathrm{~d}$ & $1.527 \pm 0.043 \mathrm{~b}$ & $1.481 \pm 0.043 \mathrm{~b}$ & $2.044 \pm 0.061 \mathrm{~d}$ & $1.879 \pm 0.045 \mathrm{c}$ & $1.153 \pm 0.029 a$ & $1.088 \pm 0.032 \mathrm{a}$ \\
\hline Ethyl 2-hydroxypropanoate & $96.540 \pm 2.768 c$ & ND & ND & $\mathrm{ND}$ & $140.889 \pm 4.202 \mathrm{~d}$ & ND & $4.028 \pm 0.102 b$ & ND \\
\hline ALCOHOLS & \multicolumn{8}{|c|}{ (mg/L of absolute alcohol) } \\
\hline 1-Propanol & $1065.428 \pm 30.551 \mathrm{~b}$ & $1416.376 \pm 39.326 c$ & $674.938 \pm 19.093 a$ & $589.248 \pm 17.148 \mathrm{a}$ & $10,536.890 \pm 314.267 \mathrm{~d}$ & $10,521.101 \pm 249.172 \mathrm{~d}$ & $1648.119 \pm 41.702 c$ & $1625.719 \pm 47.792 \mathrm{c}$ \\
\hline 2-Methyl-1-propanol & $5287.157 \pm 151.606 \mathrm{~b}$ & $5626.924 \pm 156.231 \mathrm{~b}$ & $10,590.344 \pm 299.582 \mathrm{~d}$ & $10,111.506 \pm 294.259 \mathrm{~d}$ & $3220.649 \pm 96.057 \mathrm{a}$ & $3204.551 \pm 75.894 a$ & $7071.816 \pm 178.935 c$ & $7013.669 \pm 206.185 c$ \\
\hline 1-Butanol & $34.869 \pm 1.000 \mathrm{c}$ & $39.943 \pm 1.109 \mathrm{~d}$ & $15.869 \pm 0.449 \mathrm{~b}$ & $12.614 \pm 0.367 \mathrm{a}$ & $30.819 \pm 0.919 \mathrm{~b}$ & $30.623 \pm 0.725 \mathrm{~b}$ & $36.664 \pm 0.928 \mathrm{c}$ & $36.702 \pm 1.079 \mathrm{c}$ \\
\hline 3-Methylbutanol & $6936.398 \pm 198.897 \mathrm{~b}$ & $7324.607 \pm 203.367 \mathrm{~b}$ & $12,883.438 \pm 364.449 \mathrm{~d}$ & $13,562.804 \pm 394.696 \mathrm{~d}$ & $4980.179 \pm 148.536 a$ & $4892.402 \pm 115.867 \mathrm{a}$ & $11,712.660 \pm 296.361 \mathrm{c}$ & $11,710.791 \pm 344.270 \mathrm{c}$ \\
\hline 2-Methylbutanol & $3398.718 \pm 97.456 \mathrm{~b}$ & $3634.696 \pm 100.917 b$ & $5058.071 \pm 143.084 \mathrm{c}$ & $5199.437 \pm 151.311 c$ & $1926.010 \pm 57.444 a$ & $1900.361 \pm 45.006 a$ & $4969.325 \pm 125.737 c$ & $4971.144 \pm 146.140 \mathrm{c}$ \\
\hline 2-Phenylethanol & $803.119 \pm 23.029 \mathrm{~b}$ & $941.135 \pm 26.131 \mathrm{~b}$ & $2603.190 \pm 73.640 \mathrm{~d}$ & $2629.700 \pm 76.528 \mathrm{~d}$ & $266.199 \pm 7.939 a$ & $262.343 \pm 6.213 a$ & $1150.156 \pm 29.102 c$ & $1117.587 \pm 32.854 c$ \\
\hline Methanol & $57.906 \pm 1.660 \mathrm{~b}$ & $55.679 \pm 1.546 \mathrm{~b}$ & $35.635 \pm 1.008 \mathrm{a}$ & $33.408 \pm 0.972 \mathrm{a}$ & $80.178 \pm 2.391 \mathrm{~d}$ & $80.185 \pm 1.899 \mathrm{~d}$ & $73.497 \pm 1.860 c$ & $73.483 \pm 2.160 \mathrm{c}$ \\
\hline
\end{tabular}

Different lower case letters in rows designate statistically significant differences $(p<0.05)$ between means (Tukey's test, at a significance level of 0.05$)$. ND—not detected. 
Other common compounds in alcoholic beverages include acetals, which are rapidly formed in distillates. The most prominent of the latter group is acetaldehyde diethyl acetal (1,1-diethoxyethane), of which the highest levels among whiskies were found in malt whisky. In addition to acetaldehyde diethyl acetal, a number of acetals of higher aldehydes have been determined in spirit beverages [33]. Among determined acetals, in highest concentrations in all tested distillates occurred acetaldehyde diethyl acetal. Moreover, it was observed that distillates obtained from mashes supplemented with hop $\alpha$-acid preparation contained statistically significantly lower amount of this compound than spirits from analogous mashes without microbial protection $(p<0.05)$. No clear effect of the method of sweet mashes preparation on this acetal concentration was observed. Some of the tested distillates also exhibited small amounts of other acetals, such as isobutyraldehyde diethyl acetal and isovaleraldehyde diethyl acetal (no correlation between the method of mash preparation and origin of applied amylolytic enzymes was observed, $p>0.05$ ).

Esters are the most odor-active compounds found in fermented media, the most common are those derived from ethyl alcohol and higher alcohols. Their presence is mainly linked to yeast metabolism during ethanol fermentation, so their concentration in distillates was not significantly affected by the microbiological contamination of mashes. However, in the distillates obtained from mashes prepared with malt, the levels of ethyl acetate, ethyl decanoate, and 2-phenylethyl isobutyrate were significantly higher $(p<0.05)$ as compared to samples obtained from mashes prepared with commercial enzymes of microbial origin.

The main group of volatile compounds consists of higher alcohols, which may be produced via amino acid catabolism or carbohydrate metabolism [32]. This group is represented by 2-methylbutanol, 3-methylbutanol, 2-methylpropanol, 1-propanol, 1-butanol, and 2-phenylethanol. Higher alcohols play an important role in the formation of flavor qualities in spirits, including whisky and others. Malt Scotch whiskies are rich in higher alcohols, whose content often exceeds $2 \mathrm{~g} / \mathrm{L}$ [38]. According to the recommendations of the Polish Standard [39], the maximum concentration of those compounds in agricultural distillates used for Starka production is $5 \mathrm{~g} / \mathrm{L}$ absolute alcohol. The highest concentrations of 2- and 3-methylbutanol, 2-methylpropanol, and 2-phenylethanol were reported in distillates obtained from mashes treated with enzymes of microbial origin $(p<0.05)$. Moreover, all tested distillates contained higher alcohols in relatively high concentrations in comparison with spirits obtained in our previous work [40], distilled in an alembic with a column (on a semi-technical scale) and in an industrial 2-column continuous apparatus. Taking into account, that in this work ethanol was distilled from the mashes using a laboratory distillation unit and then distillates (containing from 20 to $23 \%$ of ethanol by volume) were refined up to approx. $43 \pm 1 \%$ in a distillation apparatus equipped with a bi-rectifier unit (dephlegmator according to Golodetz), this may explain the significant differences in concentrations of higher alcohols in the obtained distillates comparing to the ones tested previously [40]. These results indicate that, although the content of higher alcohols is strongly associated with the kind of raw material and yeast used for fermentation [41], the type of apparatus used for distillation and the process parameters can modify their content.

One of the undesirable compounds in spirit distillates is methanol, which is generated through hydrolysis of methylated pectins present in plants and fruits. While methanol does not directly affect the flavor of the distillate, it is subjected to restrictive controls owing to its high toxicity [42]. EU Regulation no. 110/2008 [2] defines acceptable concentrations of methanol in ethyl alcohol of agricultural origin (i.e., rectified spirit), wine spirits, and fruit spirits, but does not set any limits on the content of this compound in distillates of agricultural origin (i.e., raw spirits). Methanol concentrations in the tested distillates (raw spirits) was higher in samples obtained from mashes with pressure-thermal treatment of cereal grains than with the PLS method. The supplementation of mashes with hop $\alpha$-acid preparation did not cause the changes in the concentration of methyl alcohol in the distillates (Table 7). 
Principal Component Analysis of Volatile Compounds

The principal component analysis (PCA) analysis of distillates obtained using different methods of starch liberation and saccharification was carried out using concentrations of volatile compounds as variables. To estimate the number of PCA factors, which significantly affect the total variance, a double criterion was used: the own value chart and own values $>1$. Using the above criteria, the four PCA factors were identified. To isolate PCA1, PCA2, PCA3, and PCA4, the method of normalized varimax rotation was used (Table 8 ).

Table 8. Factor loadings of main four principal components for normalized varimax rotation.

\begin{tabular}{ccccc}
\hline PCA Factor & Own Value & \% of Variance & The Cumulated Own Value & Cumulative $\%$ \\
\hline PCA1 & 13.50 & 53.99 & 13.50 & 53.99 \\
PCA2 & 4.89 & 19.56 & 18.39 & 73.56 \\
PCA3 & 3.14 & 12.57 & 21.53 & 86.13 \\
PCA4 & 2.35 & 9.40 & 23.88 & 95.53 \\
\hline
\end{tabular}

The PCA1 accounted for $53.99 \%$ of total variance, while the others accounted for $19.56 \%$ (PCA2), $12.57 \%$ (PCA3), and 9.40\% (PCA4). Four principal component factors explained together 95.53\% of total variance, which proves that this is a very strong model. In the next step, the value of the charge factors for the four factors was calculated (Table 9). The selection of parameters for the PCA dimension was determined according to charge factors $>0.6$.

Table 9. Values of the charge factors $>0.6$.

\begin{tabular}{ccccc}
\hline Compound & PCA1 & PCA2 & PCA3 & PCA4 \\
\hline Acetaldehyde & $\mathbf{- 0 . 7 0 1}$ & 0.319 & -0.501 & 0.248 \\
Furfural & 0.545 & -0.068 & -0.034 & $\mathbf{0 . 8 1 0}$ \\
Isobutyraldehyde & -0.083 & -0.150 & 0.063 & $\mathbf{0 . 9 3 1}$ \\
Isovaleraldehyde & $\mathbf{0 . 7 2 1}$ & 0.210 & 0.415 & 0.513 \\
2-Methylbutyraldehyde & 0.370 & 0.486 & 0.371 & $\mathbf{0 . 6 8 8}$ \\
Phenylacetaldehyde & $\mathbf{0 . 8 3 3}$ & 0.096 & 0.134 & 0.519 \\
2,3-Butanedione & $\mathbf{- 0 . 9 7 1}$ & -0.001 & 0.085 & -0.035 \\
Acetaldehyde diethyl acetal & $\mathbf{- 0 . 7 9 3}$ & 0.544 & 0.182 & 0.009 \\
Isobutyraldehyde diethyl acetal & 0.131 & $\mathbf{0 . 7 6 1}$ & 0.035 & 0.596 \\
Isovaleraldehyde diethyl acetal & 0.547 & 0.057 & -0.105 & $\mathbf{0 . 7 1 7}$ \\
Ethyl acetate & $\mathbf{0 . 7 8 0}$ & 0.041 & 0.519 & 0.317 \\
Isoamyl acetate & -0.002 & 0.547 & $-\mathbf{0 . 7 5 5}$ & -0.230 \\
Ethyl hexanoate & -0.493 & $-\mathbf{0 . 8 4 3}$ & 0.176 & -0.041 \\
Ethyl octanoate & 0.400 & 0.101 & $-\mathbf{0 . 8 6 9}$ & 0.202 \\
Ethyl decanoate & $\mathbf{0 . 8 8 7}$ & 0.178 & 0.101 & 0.377 \\
Ethyl hexadecanoate & -0.305 & -0.099 & $-\mathbf{0 . 8 5 6}$ & 0.081 \\
2-Phenylethyl isobutyrate & $\mathbf{0 . 8 1 8}$ & 0.225 & -0.419 & 0.299 \\
Ethyl 2-hydroxypropionate & 0.386 & 0.042 & -0.098 & $\mathbf{0 . 8 7 4}$ \\
1-Propanol & $\mathbf{0 . 6 4 3}$ & 0.183 & $\mathbf{0 . 6 6 4}$ & 0.306 \\
2-Methyl-1-propanol & $\mathbf{- 0 . 8 3 4}$ & 0.343 & -0.301 & -0.300 \\
1-Butanol & 0.420 & $-\mathbf{0 . 8 8 1}$ & 0.033 & 0.079 \\
3-Methylbutanol & $\mathbf{- 0 . 9 2 7}$ & 0.113 & -0.107 & -0.307 \\
2-Methylbutanol & $\mathbf{- 0 . 8 9 1}$ & -0.071 & -0.254 & -0.331 \\
2-Phenylethanol & $\mathbf{- 0 . 7 4 4}$ & 0.507 & -0.316 & -0.292 \\
Methanol & 0.439 & -0.575 & $\mathbf{0 . 6 3 0}$ & 0.272 \\
\hline
\end{tabular}

The PCA1, PCA2, PCA3, and PCA4 variables are marked in bold.

Factors for these dimensions are high. The following assignment to PCA was obtained $((+)$ - parameter takes higher value; (-) - parameter takes lower value): 
- PCA1: (Acetaldehyde (-), Isovaleraldehyde $(+)$, Phenylacetaldehyde $(+), 2,3$-butanedione $(-)$, Acetaldehyde diethyl acetal $(-)$, Ethyl acetate $(+)$, Ethyl decanoate $(+)$, 2-Phenylethyl isobutyrate (+), 1-propanol (+), 2-methyl-1-propanol (-), 3-methylbutanol (-), 2-methylbutanol $(-)$, 2-phenylethanol).

- PCA2: (Isobutyraldehyde diethyl acetal (+), Ethyl hexanoate (-), 1-butanol).

- PCA3: (Isoamyl acetate (-), Ethyl octanoate (-), Ethyl hexadecanoate (-), Methanol (+)).

- PCA4: (Furfural (+), Isobutyraldehyde (+), Isovaleraldehyde diethyl acetal (+), 2-Methylbutyraldehyde (+), Ethyl 2-hydroxypropanoate (+)).

Due to the character of quantitative PCA parameters and their positive and negative correlations, the Cronbach's Alpha coefficients were not counted. The data presented in Table 10 summarize the descriptive statistics for all factors of the PCA. Quantitatively, the largest group of volatile compounds determined in the obtained distillates is alcohols. Its concentration was in a broad range. Moreover, in the case of 1-propanol, the standard deviation value was even higher than the mean value. The second abundant group of volatile compounds is esters, where the largest differences in the concentrations were related to ethyl 2-hydroxypropanoate. Similar results have been obtained for some aldehydes (isovaleraldehyde, phenylacetaldehyde, 2-methylbutyraldehyde and furfural), acetals (isovaleraldehyde diethyl acetal and isobutyraldehyde diethyl acetal), and 2,3-butanedione.

Table 10. Descriptive statistics for determined volatile compounds grouped into principal component analysis (PCA) factors.

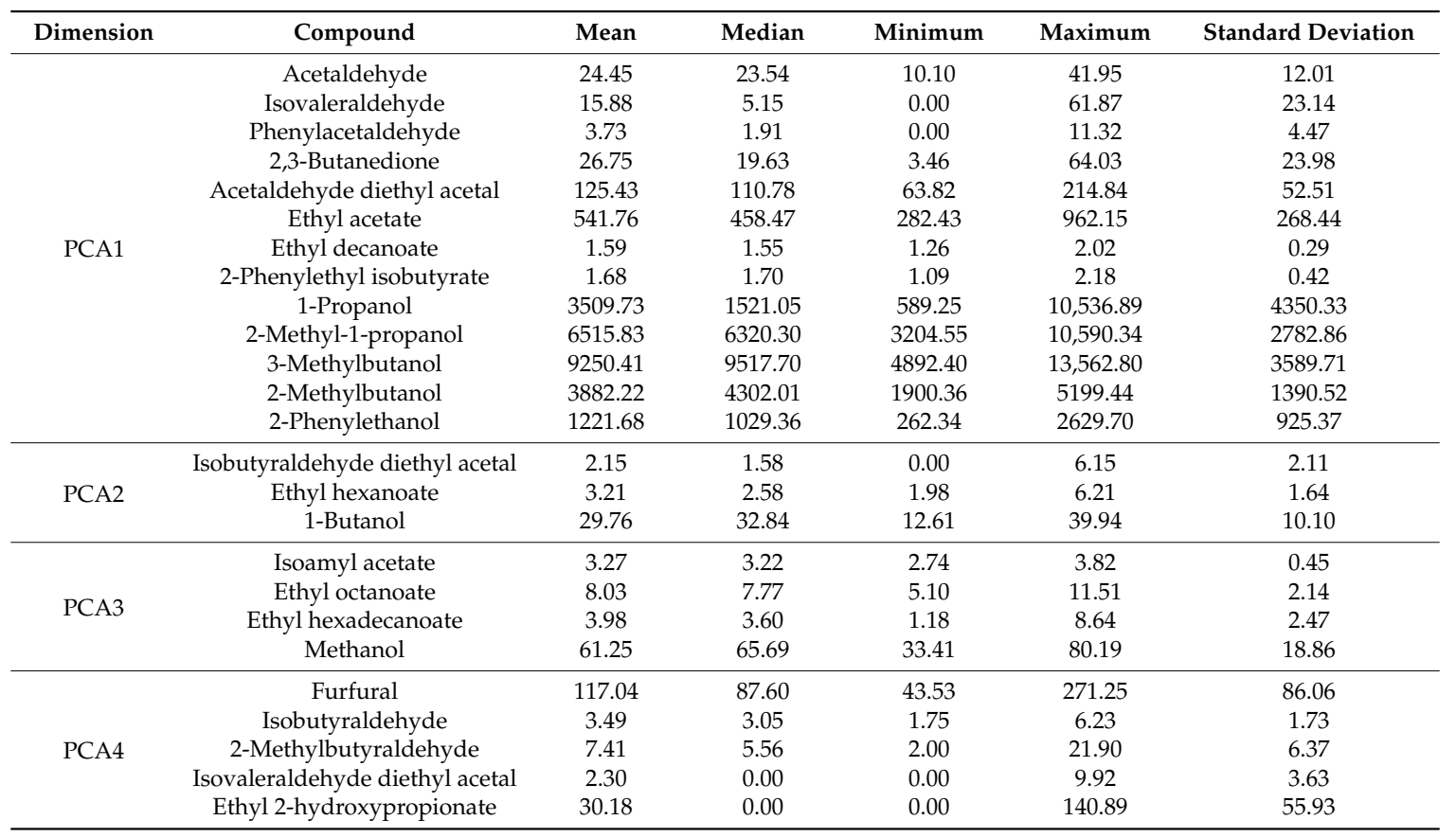

In the last part of the analysis, observations were classified based on their correlation to the each PCA factor (Table 11). The PCA4 factor (0.247) is mostly associated to the method of thermal-pressure starch liberation coupled with using of malt enzymes using during starch hydrolysis (thermal pressure method, Munich Malt type II, with addition of $\alpha$-hop acids). However, due to the fact that it is more closely related to PCA1 (0.557), it has the strongest relationship with this first component. 
Table 11. Squared cosines of the observations.

\begin{tabular}{ccccc}
\hline Method of Starch Liberation \& Saccharification & PCA1 & PCA2 & PCA3 & PCA4 \\
\hline $\begin{array}{c}\text { PLS (source of enzymes-malt) } \\
\text { Without addition of hop } \alpha \text {-acids }\end{array}$ & 0.146 & 0.176 & $\mathbf{0 . 4 5 1}$ & 0.163 \\
\hline $\begin{array}{c}\text { PLS (source of enzymes-malt) } \\
\text { With addition of hop } \alpha \text {-acids }\end{array}$ & 0.047 & 0.001 & $\mathbf{0 . 6 9 5}$ & 0.097 \\
\hline $\begin{array}{c}\text { PLS (source of enzymes—enzyme preparations) } \\
\text { Without addition of hop } \alpha \text {-acids }\end{array}$ & $\mathbf{0 . 6 6 1}$ & 0.264 & 0.052 & 0.000 \\
\hline $\begin{array}{c}\text { PLS (source of enzymes—enzyme preparations) } \\
\text { With addition of hop } \alpha \text {-acids }\end{array}$ & $\mathbf{0 . 6 6 6}$ & 0.198 & 0.033 & 0.080 \\
\hline $\begin{array}{c}\text { Thermal-pressure (source of enzymes-malt) } \\
\text { Without addition of hop } \alpha \text {-acids }\end{array}$ & $\mathbf{0 . 8 3 6}$ & 0.035 & 0.096 & 0.021 \\
\hline $\begin{array}{c}\text { Thermal-pressure (source of enzymes-malt) } \\
\text { With addition of hop } \alpha \text {-acids }\end{array}$ & $\mathbf{0 . 5 5 7}$ & 0.127 & 0.012 & 0.247 \\
\hline $\begin{array}{c}\text { Thermal-pressure (source of enzymes—enzyme preparations) } \\
\text { Without addition of hop } \alpha \text {-acids }\end{array}$ & 0.308 & $\mathbf{0 . 3 4 7}$ & 0.039 & 0.260 \\
\hline $\begin{array}{c}\text { Thermal-pressure (source of enzymes—enzyme preparations) } \\
\text { With addition of hop } \alpha \text {-acids }\end{array}$ & 0.273 & $\mathbf{0 . 6 4 1}$ & 0.000 & 0.000 \\
\hline
\end{tabular}

Values in bold correspond for each observation to the factor for which the squared cosine is the largest.

\section{Materials and Methods}

\subsection{Materials}

The following materials were used in the study:

- barley grain of the Karakan variety ("Danko" Plant Breeding Ltd., Choryń, Poland);

- $\quad$ malted grain of Munich malt type 2 spring barley (Weyermann ${ }^{\circledR}$, Bamberg, Germany);

- dry distillery yeast (Saccharomyces cerevisiae) Ethanol Red (Fermentis, a division of S.I. Lesaffre, Marcq en Baroeul Cedex, France) at a dose of $0.5 \mathrm{~g}$ d.m./L;

- enzyme preparations: Termamyl S.C. $\alpha$-amylase preparation was used for liquefaction at a dose of $0.13 \mathrm{~mL}$ per $1 \mathrm{~kg}$ starch and SAN Extra glucoamylase preparation was used for saccharification at $0.6 \mathrm{~mL}$ per $1 \mathrm{~kg}$ starch (Novozymes, Bagsværd, Denmark);

- mineral nutrient for yeast -an aqueous solution of $\left(\mathrm{NH}_{4}\right)_{2} \mathrm{HPO}_{4}$ at a dose of $0.2 \mathrm{~g} / \mathrm{L}$ mash;

- IsoStab ${ }^{\circledR}$ hop $\alpha$-acid preparation (BetaTec $\mathrm{GmbH}$, Nürnberg, Germany) as an antimicrobial agent at a dose of $80 \mathrm{ppm}$.

\subsection{Analytical Methods}

Starchy raw materials — both malted and unmalted barley grains were analyzed for starch, reducing sugars, total nitrogen, and moisture content. Starch content was measured using the Ewers polarimetric method [43]. The concentration of reducing sugars was determined using the DNS reagent [44]. Grain humidity was measured in a WPS-305 Radwag weighing dryer $\left(105^{\circ} \mathrm{C}\right)$. Total nitrogen was determined by the Kjeldahl method, calculated as protein $(\mathrm{N} \times 5.7)$ and expressed as percentage of dry weight [45].

Sweet and fermented mashes - the concentration of sugars, ethanol, and soluble solids (expressed as total extract), as well as $\mathrm{pH}$, was determined in mashes before $(0 \mathrm{~h})$ and after fermentation $(72 \mathrm{~h})$.

Sugar (glucose, maltose, and maltotriose) and ethanol content was determined by HPLC using an Infinity 1260 liquid chromatograph (Agilent Technologies, Santa Clara, CA, USA) with a refractometer detector (RID). The compounds were separated on a Hi-Plex H column $(7.7 \times 300 \mathrm{~mm}, 8 \mu \mathrm{m}$, Agilent Technologies, USA) at $60{ }^{\circ} \mathrm{C}$ using sulfuric acid $\left(\mathrm{H}_{2} \mathrm{SO}_{4}, 0.005 \mathrm{M}\right)$ as a mobile phase with a flow rate of $0.7 \mathrm{~mL} / \mathrm{min}$ and at an injection volume of $20 \mu \mathrm{L}$. The concentration of each compound was determined 
by measuring the area of the peak in relation to the peak area of the standard solutions (using the external standard method).

The concentration of total sugars (reducing sugars and dextrins after acid hydrolysis) was determined using the DNS reagent and expressed in g glucose/L mash [44]. To determine the degree of starch hydrolysis, dextrin content was calculated as the difference between total sugars and reducing sugars, using a conversion coefficient of 0.9 , finally expressed in $\mathrm{g} / \mathrm{L}$ mash.

The concentration of soluble solids (mostly sugars) in sweet mashes was measured with a hydrometer (results were expressed in $\mathrm{g} / \mathrm{kg}$ ) [24]. Upon completion of the fermentation process, the concentration of soluble solids was determined in mashes after ethanol distillation in a Super Dee digital distilling unit (Gibertini, Novate Milanese, Italy).

Microbial analysis of mashes - sweet mashes $(0 \mathrm{~h})$, mashes during fermentation (after 24 and $48 \mathrm{~h}$ ), as well as fermented mashes (after $72 \mathrm{~h}$ ) were analyzed for yeast [46] (DRBC medium, BTL Ltd., Lodz, Poland; growth conditions: $25^{\circ} \mathrm{C}, 5$ days), LAB (MRS medium, BTL Ltd., Poland; anaerobic growth conditions: $30^{\circ} \mathrm{C}, 72 \mathrm{~h}$ ), and total mesophilic bacteria (TMB) [47] (PCA medium, with nystatin, BTL Ltd., Poland; growth conditions: $30^{\circ} \mathrm{C}, 72 \mathrm{~h}$ ). Samples of mashes were prepared for microbial analysis according to ISO 6887 [48]. The limit of detection of the above enumeration techniques was $10 \mathrm{cfu} / \mathrm{mL}$. The results were expressed as $\log \mathrm{cfu} / \mathrm{mL}$.

Analysis of distillates - distillates were quantitatively analyzed for volatile compounds by means of gas chromatography using a GC apparatus (Agilent 7890A, Agilent Technologies, Santa Clara, CA, USA) coupled with a mass spectrometer (Agilent MSD 5975C, Agilent Technologies, Santa Clara, CA, USA). A capillary column was used to separate compounds (Agilent VF-WAX MS; $60 \mathrm{~m} \times$ $0.50 \mu \mathrm{m} \times 0.32 \mathrm{~mm}$ ). The $\mathrm{GC}$ oven temperature was programmed from $40(6 \mathrm{~min})$ to $80^{\circ} \mathrm{C}$ at a rate of $2{ }^{\circ} \mathrm{C} / \mathrm{min}$, and then increased to $220^{\circ} \mathrm{C}$ at a rate of $10^{\circ} \mathrm{C} / \mathrm{min}$ and maintained for $5 \mathrm{~min}$. The flow rate of the carrier gas (helium) through the column was $2.0 \mathrm{~mL} / \mathrm{min}$. The temperature of the injector (split/splitless) was $250{ }^{\circ} \mathrm{C}$. Direct injections of the tested distillates $(1 \mu \mathrm{L})$ were made in the split mode (1:40). The temperature of the MS ion source, transfer line, and quadrupole was $230{ }^{\circ} \mathrm{C}, 250{ }^{\circ} \mathrm{C}$, and $150{ }^{\circ} \mathrm{C}$, respectively. The ionization energy was $70 \mathrm{eV}$.

Identification of the volatile components was based on the comparison of their mass spectra with the mass spectra in the NIST/EPA/NIH Mass Spectra Library (2012; Version 2.0g.). Moreover, retention indices (RIs) were compared with reference compounds and literature data [49,50]. RIs were calculated according to the formula proposed by van den Dool and Kratz [51] relative to a homologous series of n-alkanes from pentane to octadecane. Quantification of the volatile compounds was done using calibration curves in the selected ion monitoring mode (SIM). Six calibration solutions containing different concentrations of each standard compound were prepared with 4-heptanone, which was added at a concentration of $45 \mathrm{mg} / \mathrm{L}$ of absolute alcohol to the analyzed samples as an internal standard to monitor instrument response and retention time stability. Quantitative analysis was performed using Agilent MassHunter software (Agilent Technologies, Santa Clara, CA, USA). The results were expressed in $\mathrm{mg} / \mathrm{L}$ of absolute alcohol.

\subsection{Preparation of Sweet Mashes}

Sweet mashes were prepared both by pressureless starch liberation (PLS) and by the pressurethermal method.

PLS method-mashes were prepared in a cylindrical steel vessel with a depth of $300 \mathrm{~mm}$ and an internal diameter of $330 \mathrm{~mm}$ (working volume-19 L), equipped with a heating/cooling coil and a thermometer, pursuant to the following procedures:

- mashing with malt enzymes $-0.6 \mathrm{~kg}$ of barley grain and $0.6 \mathrm{~kg}$ of Munich malt type 2 grain was ground and mixed (1:1) with water $(3.5 \mathrm{~L}$ per $1 \mathrm{~kg})$. The mixture was continuously stirred by an overhead stirrer (CAT, R50) and heated to $53-56{ }^{\circ} \mathrm{C}$. The mash was kept at this temperature for $60 \mathrm{~min}$ to conduct starch liquefaction and saccharification ( $\mathrm{pH}$ was kept at 5.3), and then cooled down to $30^{\circ} \mathrm{C}$. 
- $\quad$ mashing with enzyme preparations $-1.2 \mathrm{~kg}$ of barley grain was ground and mixed with water $\left(3.5 \mathrm{~L}\right.$ per $1 \mathrm{~kg}$ ) previously heated to $50^{\circ} \mathrm{C}$. The mixture was continuously stirred by an overhead stirrer and heated to $90^{\circ} \mathrm{C}$, and then treated with the liquefying Termamyl S.C. preparation. The mixture was kept for $60 \mathrm{~min}$ at this temperature ( $\mathrm{pH}$ was kept at 5.5), then cooled to $65^{\circ} \mathrm{C}$ and treated with the saccharifying SAN Extra preparation. Directly after the addition of SAN Extra, the mash was cooled down to $30^{\circ} \mathrm{C}$.

Pressure-thermal method $-5 \mathrm{~kg}$ of barley grain was placed in a tapered cylindrical steamer (cylindrical part dimensions: $210 \mathrm{~mm}$ depth and $304 \mathrm{~mm}$ internal diameter; tapered part dimensions: $640 \mathrm{~mm}$ depth with inclination angle of walls $12^{\circ}$; total volume $-40 \mathrm{~L}$; working volume-30 L) previously filled with $17.5 \mathrm{~L}$ of water heated to the boiling point, and the steamer was then closed. The raw material was steamed at $150{ }^{\circ} \mathrm{C}$ and a pressure of $0.4 \mathrm{MPa}$ for $35 \mathrm{~min}$, with periodical circulation of the content. Upon completion of this step, the content of the steamer was transferred to a cylindrical steel-mashing vessel with a depth of $340 \mathrm{~mm}$ and an internal diameter of $300 \mathrm{~mm}$ (working volume-19 L), equipped with a heating/cooling coil and a thermometer, and the mashing process was carried out pursuant to the following procedures:

- The steamed mass was continuously stirred by an overhead stirrer and cooled down to $53-56{ }^{\circ} \mathrm{C}$. At the same time, barley Munich malt type 2 was ground and mixed with warm water (heated to $53-56{ }^{\circ} \mathrm{C}$ ), and the obtained mixture was added to the mashing vessel in a ratio of 1:1 (1 part unmalted grain to 1 part malted grain, $w / w)$. The mixture was kept at $53-56{ }^{\circ} \mathrm{C}$ for $60 \mathrm{~min}$ to conduct starch liquefaction and saccharification ( $\mathrm{pH}$ was kept at 5.3), and then cooled to $30^{\circ} \mathrm{C}$.

- The steamed mass was continuously stirred by an overhead stirrer and cooled to $90{ }^{\circ} \mathrm{C}$, then treated with the liquefying Termamyl S.C. preparation. The mixture was kept for $60 \mathrm{~min}$ at this temperature ( $\mathrm{pH}$ was kept at 5.5), then cooled down to $65^{\circ} \mathrm{C}$ and treated with the saccharifying SAN Extra preparation. Immediately after the addition of SAN Extra, the mash was cooled down to $30^{\circ} \mathrm{C}$.

\subsection{Fermentation Process}

Fermentation was carried out using dry distillery yeast Ethanol Red (Saccharomyces cerevisiae). Prior to fermentation (i.e., before mashes inoculation), a yeast slurry was prepared according to the procedure described earlier [24] to eliminate undesirable bacterial cells.

The yeast slurry was added to the sweet mash in the amount of $0.5 \mathrm{~g}$ of dry yeast per $1 \mathrm{~L}$ of mash. The inoculated mashes were also supplemented with diammonium phosphate $(0.2 \mathrm{~g} / \mathrm{L})$ and finally mixed. The IsoStab ${ }^{\circledR}$ hop $\alpha$-acid preparation (BetaTec GmbH, Nürnberg, Germany) was added as an inhibitor of microbial infections in selected trials in the amount of $80 \mathrm{mg} / \mathrm{L}$. All fermentation trials were conducted for 3 days, at $35-38^{\circ} \mathrm{C}$; initial $\mathrm{pH}$ of mashes was 4.8 .

\subsection{Distillation}

Upon completion of the fermentation, ethyl alcohol was distilled from the mashes [24].

\subsection{Calculations}

Fermentation efficiency and total sugar intake were calculated to evaluate the fermentation process [24].

\subsection{Statistical Analysis}

All experiments were performed in triplicate. Statistical analysis was performed using STATISTICA 10.0 software (StatSoft, Tulsa, OK, USA). The obtained results were evaluated using one-way or two-way analysis of variance (ANOVA, at the 0.05 significance level) to indicate differences. If statistical differences were detected $(p<0.05)$, means were compared by Tukey's test (at the 0.05 significance level). 
PCA was used to determine the best differentiation of volatile compounds in the distillates obtained using different methods of starch liberation and saccharification. Moreover, for evaluation of the results of microbial analysis, the discriminant function analysis was used.

\section{Conclusions}

Spirit beverages, such as vodka, whisky, korn, and others, produced from fermented grain mashes are known and appreciated around the world for their organoleptic characteristics. The rising requirements of foods and alcoholic beverages, especially organic products, are the main factors indicating the need to apply technological innovations with a simultaneous monitoring of industrial processes. In the distilling industry, this implies an evaluation of the efficiency of the alcoholic fermentation process and the quality (i.e., appropriate chemical composition and desirable taste and aroma) of the final product (agricultural distillate).

The use of the PLS method in conjunction with malt as a source of amylolytic enzymes is an interesting option, especially in the context of the production of organic spirits. The idea of organic spirits (including vodka) involves a reduction in emissions of harmful pollutants to the environment thanks to novel technological solutions and the use of organic raw materials (cereals, yeast, and enzymes). Nevertheless, special attention should be paid to microbiological purity during production.

The results of our research has shown that the use of malt in the mashing of cereal raw materials, pretreated both by the pressure-thermal and pressureless methods, causes significant contamination of the resulting sweet mashes with lactic acid bacteria. Without the use of antimicrobial protection, bacteria counts are likely to increase, reducing ethanol yield as a result of metabolite (lactic and acetic acids) production and competition for nutrients.

Plant-derived compounds known for their antimicrobial properties against Gram-positive bacteria, such as hop $\alpha$-acids, can alleviate the presence of LAB, which are the most widespread distillery contaminants. In our study, the antibacterial properties of hop $\alpha$-acids were shown to reduce LAB content in mashes obtained by the PLS method with malt to less than $4 \log \mathrm{cfu} / \mathrm{mL}$ and increase ethanol yield by $17 \%$ to $78.88 \pm 2.69 \%$ of the theoretical value, in comparison with the control sample.

The obtained results indicate differences in the concentrations of the volatile compounds in cereal distillates that were mainly affected by a source of amylolytic enzymes applied for starch saccharification during the production of distillery mashes. Distillery mashes prepared from barley mixed with malt resulted in distillates richer in aroma compounds such as esters of fatty acids (ethyl octanoate, ethyl decanoate, and ethyl hexadecanoate) and aldehydes (phenylacetaldehyde). Additionally, bacterial microflora resulted in the formation of aroma-active compound such as ethyl 2-hydroxypropanoate.

Acknowledgments: This work was supported by the Polish National Centre for Research and Development under Grant PBS2/B8/9/2013.

Author Contributions: K.P.-P. and M.B. conceived and designed the experiments; K.P.-P, M.B., A.N., M.W., A.C., U.D.-K., and P.P. performed the experiments; K.P.-P and M.B. analyzed the data; and K.P.-P and M.B. wrote the paper.

Conflicts of Interest: The authors declare no conflict of interest.

\section{References}

1. European Union (EU). Council Regulation (EC) No 834/2007 of 28 June 2007 on Organic Production and Labelling of Organic Products and Repealing Regulation (EEC) No 2092/91; The Publications Office of the European Union: Luxembourg, 2007; p. L189/1.

2. European Union (EU). Regulation (EC) No 110/2008 of the European Parliament and of the Council of 15 January 2008 on the Definition, Description, Presentation, Labelling and the Protection of Geographical Indications of Spirit Drinks and Repealing Council Regulation (EEC) No 1576/89; The Publications Office of the European Union: Luxembourg, 2008. 
3. De Souza, P.M.; de Oliveira, M.P. Application of microbial $\alpha$-amylase in industry-A review. Braz. J. Microbiol. 2010, 41, 850-861. [CrossRef] [PubMed]

4. Gurung, N.; Ray, S.; Bose, S.; Rai, V. A broader view: Microbial enzymes and their relevance in industries, medicine, and beyond. BioMed Res. Int. 2013, 2013. Article ID 329121. [CrossRef]

5. Muller, R. The effects of mashing temperature and mash thickness on wort carbohydrate composition. J. Inst. Brew. 1991, 97, 85-92. [CrossRef]

6. Donga, L.; Piaoc, Y.; Zhangd, X.; Zhaob, C.; Houb, Y.; Shia, Z. Analysis of volatile compounds from a malting process using headspace solid-phase micro-extraction and GC-MS. Food Res. Int. 2013, 51, 783-789. [CrossRef]

7. Skinner, K.A.; Leathers, T.D. Bacterial contaminants of fuel ethanol production. J. Ind. Microbiol. Biotechnol. 2004, 31, 401-408. [CrossRef] [PubMed]

8. Broda, M.; Grajek, W. Microbial contaminations during bioethanol production. Sci. Tech. Mag. Ferment. Fruit Veg. Ind. 2009, 7-8, 58-60.

9. Beckner, M.; Ivey, M.L.; Phister, T.G. Microbial contamination of fuel ethanol fermentations. Lett. Appl. Microbiol. 2011, 53, 387-394. [CrossRef] [PubMed]

10. Muthaiyan, A.; Limayem, A.; Rücke, S. Antimicrobial strategies for limiting bacterial contaminants in fuel bioethanol fermentations. Prog. Energy Combust. Sci. 2011, 37, 351-370. [CrossRef]

11. Broda, M.; Leja, K. The microbiological situation of distilleries in Poland. Pol. J. Environ. Stud. 2010, 19, 901-906.

12. O'Sullivan, T.F.; Walsh, Y.; O'Mahonyi, A.; Fitzgerald, G.F.; van Sinderen, D. A comparative study of malthouse and brewhouse microflora. J. Inst. Brew. 1999, 105, 55-61. [CrossRef]

13. Narendranath, N.V. Bacterial contamination and control in ethanol production. In The Alcohol Textbook, 4th ed.; Jacques, K.A., Lyons, T.P., Kelsall, D.R., Eds.; Nottingham University: Nottingham, UK, 2003; Volume 20, pp. 287-298. ISBN 1-897676-13-1.

14. Narendranath, N.V.; Power, R. Relationship between $\mathrm{pH}$ and medium dissolved solids in terms of growth and metabolism of Lactobacilli and Sacharomyces cerevisiae during ethanol production. Appl. Environ. Microbiol. 2005, 71, 2239-2243. [CrossRef] [PubMed]

15. Sakamotoa, K.; Konings, W.N. Beer spoilage bacteria and hop resistance. Int. J. Food Microbiol. 2003, 89, 105-124. [CrossRef]

16. Faour, S. Bacterial Inhibition without Antibiotics. Ethanol Producer Magazine, 2012. Available online: http:/ / www.ethanolproducer.com/articles/9014/bacterial-inhibition-without-antibiotics (accessed on 12 June 2017).

17. Rückle, L.; Senn, T. Hop acids can efficiently replace antibiotics in ethanol production. Int. Sugar J. 2006, 108, 139-147.

18. Blümelhuber, G. Cereals, malts and hops. Brauwelt Int. 2012, 2, 75-83.

19. Pyler, R.E.; Thomas, D.A. Malted cereals: Their production and use. In Handbook of Cereal Science and Technology, 2nd ed.; Kulp, K., Ponte, J.G., Eds.; Marcel Dekker Inc.: New York, NY, USA, 2000; Volume 22, pp. 688-691, ISBN 9780824782948.

20. Briggs, D.E.; Boulton, C.A.; Brookes, P.A.; Stevens, R. Brewing: Science and Practice; Woodhead Publishing Limited: Cambridge, UK, 2004; p. 28, ISBN 9780849325472.

21. Montanuci, F.D.; de Matos Jorge, L.M.; Matos Jorge, R.M. Kinetic, thermodynamic properties, and optimization of barley hydration. Food Sci. Technol. 2013, 33. No. 4. [CrossRef]

22. Baks, T.; Bruins, M.E.; Matser, A.M.; Janssen, A.E.M.; Boom, R.M. Effect of gelatinization and hydrolysis conditions on the selectivity of starch hydrolysis with $\alpha$-amylase from Bacillus licheniformis. J. Agric. Food Chem. 2008, 56, 488-495. [CrossRef]

23. Bao, J. The functionality of rice starch. In Starch in Food: Structure, Function and Applications; Eliasson, A.C., Ed.; Woodhead Publishing Limited: Cambridge, UK, 2004; Volume 9, p. 282, ISBN 978-1-85573-731-0.

24. Balcerek, M.; Pielech-Przybylska, K.; Strąk, E.; Patelski, P.; Dziekońska, U. Comparison of fermentation results and quality of the agricultural distillates obtained by application of commercial amylolytic preparations and cereal malts. Eur. Food Res. Technol. 2016, 242, 321-335. [CrossRef]

25. Narendranath, N.V.; Thomas, K.C.; Ingledew, W.M. Effects of acetic acid and lactic acid on the growth of Saccharomyces cerevisiae in a minimal medium. J. Ind. Microbiol. Biotechnol. 2001, 26, 171-177. [CrossRef] [PubMed] 
26. Thomas, K.C.; Hynes, S.H.; Ingledew, W.M. Effect of lactobacilli on yeast growth, viability and batch and semi-continuous alcoholic fermentation of corn mash. J. Appl. Microbiol. 2001, 90, 819-828. [CrossRef] [PubMed]

27. De Giori, G.; de Valdez, G.; de Ruiz Holgado, A.; Oliver, G. Effect of pH and temperature on the proteolytic activity of lactic acid bacteria. J. Diary Sci. 1985, 68, 2160-2164. [CrossRef]

28. Jurkowski, M.; Błaszczyk, M. Physiology and biochemistry of lactic acid bacteria. Kosmos 2012, 61, $493-504$.

29. Van Cleemput, M.; Cattoor, K.; de Bosscher, K.; Haegeman, G.; de Keukeleire, D.; Heyerick, A. Hop (Humulus lupulus)-derived bitter acids as multipotent bioactive compounds. J. Nat. Prod. 2009, 72, 1220-1230. [CrossRef] [PubMed]

30. Buśko, M.; Jeleń, H.; Góral, T.; Chmielewski, J.; Stuper, K.; Szwajkowska-Michałek, L.; Tyrakowska, B.; Perkowski, J. Volatile metabolites in various cereal grains. Food Addit. Contam. 2010, 27, 1574-1581. [CrossRef] [PubMed]

31. Dragone, G.; Mussatto, S.I.; Oliveira, J.M.; Teixeira, J.A. Characterisation of volatile compounds in an alcoholic beverage produced by whey fermentation. Food Chem. 2009, 112, 929-935. [CrossRef]

32. Russell, I. Understanding yeast fundamentals. In The Alcohol Textbook, 4th ed.; Jacques, K.A., Lyons, T.P., Kelsall, D.R., Eds.; Nottingham University: Nottingham, UK, 2003; Volume 9, pp. 85-119, ISBN 1-897676-13-1.

33. Nykänen, L.; Nykänen, I. Distilled beverages. In Volatile Compounds in Foods and Beverages; Maarse, H., Ed.; Marcel Dekker Inc.: New York, NY, USA, 1991; Volume 16, pp. 548-552, ISBN 0-8247-8390-5.

34. Hofmann, T.; Schieberle, P. Thermal processing: More than extending the shelf life of foods. In Thermal Processing of Food: Potential Health Benefits and Risks; Eisenbrand, G., Engel, K.H., Grunow, W., Hartwig, A., Knorr, D., Knudsen, I., Schlatter, J., Schreier, P., Steinberg, P., Vieths, S., Eds.; WILEY-VCH Verlag GmbH \& Co. KGaA: Weinheim, Germany, 2007; Volume 4, p. 35, ISBN 9783527319091.

35. De Clippeleer, J.; de Rouck, G.; de Cooman, L.; Aerts, G. Influence of the hopping technology on the storage-induced appearance of staling aldehydes in beer. J. Inst. Brew. 2010, 116, 381-398. [CrossRef]

36. Berger, R.G. Application of genetic methods to the generation of volatile flavors. In Food Biotechnology: Microorganisms; Hui, Y.H., Khachatourians, G.G., Eds.; WILEY-VCH, Inc.: Hoboken, NJ, USA, 1995; Volume No. 7, p. 286, ISBN 978-0-471-18570-3.

37. Barbour, E.A.; Priest, F.G. Some effects of Lactobacillus contamination in Scotch whisky fermentations. J. Inst. Brew. 1988, 94, 89-92. [CrossRef]

38. Lyons, T.P. Production of scotch and irish whiskies: Their history and evolution. In Alcohol Textbook, 4th ed.; Jacques, K.A., Lyons, T.P., Kelsall, D.R., Eds.; Alltech Inc.: Nicholasville, KY, USA, 2003; Volume 14, pp. 193-206. ISBN 1-897676-13-1.

39. Polish Committee for Standardization. Polish Standard PN-A-79523:2002. Agricultural Distillate; Polish Committee for Standardization: Warsaw, Poland, 2002; pp. 1-7.

40. Balcerek, M.; Pielech-Przybylska, K.; Dziekońska-Kubczak, U.; Patelski, P.; Strąk, E. Fermentation results and chemical composition of agricultural distillates obtained from rye and barley grains and the corresponding malts as a source of amylolytic enzymes and starch. Molecules 2016, 21, 1320. [CrossRef] [PubMed]

41. Kłosowski, G.; Mikulski, D.; Macko, D.; Miklaszewska, B.; Kotarska, K.; Czupryński, B. Influence of various yeast strains and selected starchy raw materials on production of higher alcohols during the alcoholic fermentation process. Eur. Food Res. Technol. 2015, 240, 233-242. [CrossRef]

42. Adam, L.; Versini, G.A. Study on the Possibilities to Lower the Content of Methyl-Alcohol in Eaux-de-vie de Fruits; European Commission: Brussels, Belgium, 1996; pp. 1-8, ISBN 92-827-7208-X.

43. British Standards Institution. BS EN ISO 10520:1998. In Native Starch. Determination of Starch Content. Ewers Polarimetric Method; British Standards Institution: London, UK, 1998.

44. Miller, G.L. Use of dinitrosalicylic acid reagent for determination of reducing sugar. Anal. Chem. 1959, 31, 426-428. [CrossRef]

45. Official Methods of Analysis of AOAC International, 16th ed.; Method 960.52; AOAC International: Rockville, MD, USA, 1995.

46. International Organization for Standardization. ISO 21527-1:2008. Microbiology of Food and Animal Feeding Stuffs. Horizontal Method for the Enumeration of Yeasts and Moulds. Part 1: Colony Count Technique in Products with Water Activity Greater than 0.95; International Organization for Standardization: Geneva, Switzerland, 2008. 
47. International Organization for Standardization. ISO 4833:2004. Microbiology of Food and Animal Feeding Stuffs. Horizontal Method for the Enumeration of Microorganisms. Colony-Count Technique at 30 Degrees C; International Organization for Standardization: Geneva, Switzerland, 2003.

48. International Organization for Standardization. ISO 6887-1:1999. Microbiology of Food and Animal Feeding Stuffs-Preparation of Test Samples, Initial Suspension and Decimal Dilutions for Microbiological Examination; International Organization for Standardization: Geneva, Switzerland, 1999.

49. Chida, M.; Sone, Y.; Tamur, H. Aroma characteristics of stored tobacco cut leaves analyzed by a high vacuum distillation and canister system. J. Agric. Food. Chem. 2004, 52, 7918-7924. [CrossRef] [PubMed]

50. Mahattanatawee, K.; Goodner, K.L.; Baldwin, E.A. Volatile constituents and character impact compounds of selected Florida's tropical fruit. Proc. Fla. State Hort. Soc. 2005, 118, 414-418.

51. Van den Dool, H.; Kratz, P.D. A generalization of the retention index system including linear temperature programmed gas-liquid partition chromatography. J. Chromatogr. A. 1963, 11, 463-471. [CrossRef]

Sample Availability: Samples of the compounds are not available from the authors.

(C) 2017 by the authors. Licensee MDPI, Basel, Switzerland. This article is an open access article distributed under the terms and conditions of the Creative Commons Attribution (CC BY) license (http://creativecommons.org/licenses/by/4.0/). 